\title{
10. TROPICAL PACIFIC SILICOFLAGELLATE ZONATION AND PALEOTEMPERATURE TRENDS OF THE LATE CENOZOIC ${ }^{1}$
}

\author{
David Bukry, United States Geological Survey, Scripps Institution of Oceanography²
}

\begin{abstract}
Quantitative study of late Cenozoic silicoflagellates at tropical Pacific DSDP Sites 572 and 575 shows that the greatest amplitude of fluctuation in relative paleotemperature values occurred in the late Miocene. The coolest minimum paleotemperature values (near $T s=30$ ) also occurred in the late Miocene. The warmest intervals $(T s=80$ to 100$)$ occurred in the middle Miocene and late Pliocene to Quaternary. In detail, the silicoflagellate relative paleotemperature curve correlates fairly well with the eustatic sea-level curve and deep-sea hiatus sequence.

The only upper Cenozoic low-latitude biostratigraphic units not identified are the Distephanus speculum haliomma Subzone and Naviculopsis quadrata Zone, owing to the absence of the nominative species, which probably had nontropical ecologic preference. Several Naviculopsis occurrence events within the Naviculopsis ponticula Zone correlate between DSDP Hole 575A and DSDP Hole 495 off Guatemala. Many local and regional biostratigraphic events are recognized.

New taxa identified from DSDP Leg 85 include Dictyocha nola Bukry, n. sp., Distephanus stradneri var. grandis Bukry, n. var., Mesocena elliptica var. rhomboidea Bukry, n. var., and Naviculopsis obtusarca var. acicula Bukry, n. var.
\end{abstract}

\section{INTRODUCTION}

A composite section of upper Cenozoic sediment, rich in siliceous skeletons, from the equatorial Pacific at DSDP Sites 572 and 575 was studied quantitatively for silicoflagellate relative-paleotemperature trends and biostratigraphic zonation. This composite section (Hole 572A, Cores 1 to 17; Hole 572D, Cores 1 to 33; and Hole 575A, Cores 1 to 33 ) provides a tropical and openocean comparison with the previous quantitative studies of silicoflagellates recovered nearer the Pacific coast, from California to Ecuador (DSDP Legs 63 to 69). Relations examined in this study include the correlation of early Miocene Naviculopsis between DSDP Site 495, off Guatemala, and DSDP Site 575; the paleotemperature significance of Naviculopsis; and the distribution of silicoflagellates through the lower Miocene, which has been poorly known in the Pacific area. Also examined are the pattern of the $T s$ paleotemperature curve relative to $\mathrm{Pa}$ cific currents and eustatic sea-level changes. The possible changing significance of certain silicoflagellate morphologies, such as quadrate and hexagonal Distephanus, for paleotemperature is discussed with reference to previous DSDP investigations for higher latitudes.

Early occurrence data on tropical eastern Pacific silicoflagellates for DSDP Leg 9 sites were provided by D. Milow and published in Volume 9 of the Initial Reports ${ }^{3}$; those data, however, were nonquantitative. Similarly, a subsequent study of DSDP eastern Pacific silicoflagellates by Ling (1977) examined some tropical sites to pro-

\footnotetext{
${ }^{1}$ Mayer, L., Theyer, F., et al., Init. Repts. DSDP, 85: Washington (U.S. Govt. Printing Office)

${ }^{2}$ Address: United States Geological Survey, Scripps Institution of Oceanography, La Jolla, CA 92093.

${ }^{3}$ Hays et al. (1972), pp. 79-82, 237, 240, 346-348, 420, 421, 468, 469, 507-510, 558 561 , and $636-640$.
}

vide a biostratigraphic framework, but yielded no quantitative data needed for paleoecological comparison or correlation. Quantitative data for upper Cenozoic silicoflagellate assemblages are available in Volumes 16, 54, and 67 to 69 of the Initial Reports.

\section{METHODS AND MATERIALS}

Acid-residue strewn slides were prepared for 136 samples from DSDP Holes 572A, 572D, and 575A. Light-microscope counts of silicoflagellates were made at the generic level for Holes 572A and 572D; some stratigraphic and ecologic key species also were counted. The light-microscope counts of silicoflagellates were made at more detailed subgeneric levels for Hole 575A, but diversity was low in these less abundant assemblages.

Identifications were made at magnifications of $250 \times$ to $500 \times$. Broken specimens possessing the apical structure were counted as whole specimens, but other broken segments were not counted; breakage was minor, though (typically less than $5 \%$ ). Counts of 300 specimens or one complete slide area $(22 \times 40 \mathrm{~mm})$ were made to compute percentages. For the sparse assemblages of Hole $575 \mathrm{~A}$, counts were terminated at the round figures of 50 or 100 if only a little slide area remained uncounted. Percentages were not calculated for populations of less than 50 specimens because of the unlikelihood of consistent rankings.

Many of the Leg 85 samples examined are the same sample preparations used, aboard ship and ashore, for diatom studies (Barron, this volume). These samples, kindly made available by John A. Barron, permit better age control and correlation of the silicoflagellates with diatoms for Leg 85 and other eastern Pacific cruises, such as Legs 54 and 67 to 69 . Diatom ages for Leg 85 were provided by John A. Barron (personal communication, 1983).

The basis for relative paleotemperature values $(T S)$ and biostratigraphic zonation for silicoflagellates has been given by Bukry (1981a, $1981 \mathrm{~b}$, and 1983). Species distributions are compared against those at other DSDP sites in the eastern Pacific region (Fig. 1) and more distant Pacific and Atlantic sites.

\section{COMMENTS ON SILICOFLAGELLATE ZONES}

Low-latitude zones (Table 1) can be applied through the lower Miocene to the Quaternary composite section formed by DSDP Holes 572A, 572D, and 575A (Tables 2 to 5 ). The only missing biostratigraphic units, defined 


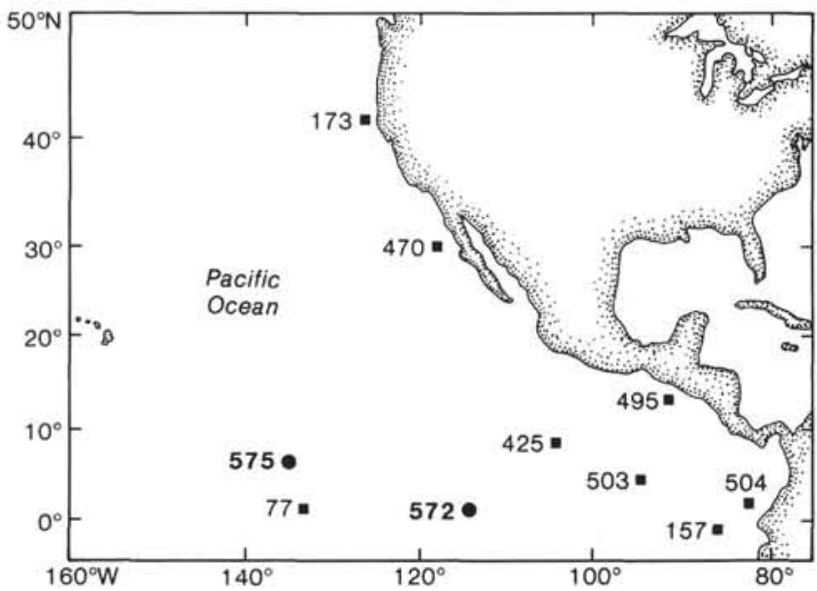

Figure 1. Locations of silicoflagellate-rich DSDP sites in the eastern Pacific, referred to in text. DSDP Leg 85 sites are shown by circles.

Table 1. Late Cenozoic low-latitude silicoflagellate zonation (Bukry, $1981 \mathrm{~b}$ and 1983).

\begin{tabular}{|c|c|c|}
\hline Age & Zone & Subzone \\
\hline \multirow{3}{*}{ Quaternary } & \multicolumn{2}{|l|}{ Dictyocha aculeata } \\
\hline & \multicolumn{2}{|l|}{ Mesocena quadrangula } \\
\hline & \multirow{2}{*}{ Dictyocha stapedia } & Dictyocha delicata \\
\hline $\begin{array}{l}\text { late } \\
\text { Pliocene }\end{array}$ & & Dictyocha ornata ornata \\
\hline \multirow{2}{*}{$\begin{array}{l}\text { early } \\
\text { Pliocene }\end{array}$} & \multirow{3}{*}{ Dictyocha fibula } & Dictyocha angulata \\
\hline & & Dictyocha pulchella \\
\hline \multirow{2}{*}{$\begin{array}{c}\text { late } \\
\text { Miocene }\end{array}$} & & Dictyocha neonautica \\
\hline & \multicolumn{2}{|l|}{ Dictyocha brevispina } \\
\hline $\begin{array}{l}\text { middle } \\
\text { Miocene }\end{array}$ & \multirow{2}{*}{ Corbisema triacantha } & Distephanus stauracanthus \\
\hline---- & & - \\
\hline \multirow{3}{*}{$\begin{array}{c}\text { early } \\
\text { Miocene }\end{array}$} & \multicolumn{2}{|l|}{ Naviculopsis ponticula } \\
\hline & \multicolumn{2}{|l|}{ Naviculopsis quadrata ${ }^{\mathrm{a}}$} \\
\hline & \multicolumn{2}{|l|}{ Naviculopsis lata } \\
\hline \multirow{2}{*}{ Oligocene } & \multirow{2}{*}{ Naviculopsis biapiculata } & Distephanus speculum haliomma $a^{\mathrm{a}}$ \\
\hline & & - \\
\hline
\end{tabular}

${ }^{a}$ Not identified at DSDP Leg 85 sites.

for low to middle latitudes (Bukry, 1981b), are the $\mathrm{Na}$ viculopsis quadrata Zone and the Distephanus speculum haliomma Subzone. The guide species for these zones are missing from the tropical assemblages of Leg 85, but are present at middle and high latitudes (e.g., DSDP Legs 38 , 41, and 49). Comments on the Leg 85 zonal assemblages follow.

\section{Naviculopsis biapiculata Zone}

The zonal assemblages of the Naviculopsis biapiculata Zone are sparse, with no Corbisema or Mesocena (Table 2). Distephanus speculum patulus, Naviculopsis biapiculata s. ampl., and $N$. constricta are the most distinctive taxa present at Hole 575A. No specimens of subzonal guide taxa Distephanus speculum haliomma or $D$. speculum hemisphaericus are present at Hole 575A, suggesting that they are more useful for biostratigraphy at middle or high latitudes, where their occurrence is more consistent. One new variety, Distephanus stradneri var. grandis, $\mathrm{n}$. var., is limited here to the $N$. biapiculata Zone.

\section{Naviculopsis lata Zone}

A transition from Distephanus schauinslandii to $D$. crux scutulatus appears to occur in the $N$. lata Zone of Hole 575A (Plate 3, Figs. 2-5, 7, 8). D. speculum patulus is prominent, along with $N$. biapiculata s. ampl. and $N$. lata (Table 3). The absences of Corbisema triacantha and the Mesocena apiculata group contrast with highlatitude assemblages preserved at DSDP Site 407 west of Iceland. $N$. lata is more abundant at tropical DSDP Site 575 (Hole 575A) than at higher-latitude sites, suggesting that $N$. lata had a warm-water preference, which makes it a good biostratigraphic guide for low latitudes.

\section{Naviculopsis quadrata Zone}

The interval between the first Naviculopsis quadrata and the first $N$. ponticula or the last $N$. quadrata defines the Naviculopsis quadrata Zone (Bukry and Foster, 1974; Bukry, 1981a). Owing to the very poor silicoflagellate assemblage in Core 13 of Hole 575A and the absence of $N$. quadrata, no $N$. quadrata Zone can be identified at Hole 575A (Table 3). The tropical location of Leg 85 sites probably precludes good representation of the $N$. quadrata Zone, because $N$. quadrata favors cooler regions. For example, high-latitude DSDP Site 338 , off Norway, has up to $16 \% N$. quadrata, whereas coeval assemblages at mid-latitude DSDP Site 369, off northwest Africa, contain a maximum of only $1 \% \mathrm{~N}$. quadrata.

The higher abundance of $N$. quadrata and the lower abundance of $N$. lata $(1$ or $2 \%$ ) at high latitude, seen for DSDP Sites 338 and 369, show a trend that is supported by the high $(48 \%)$ abundance of $N$. lata and by the absence of $N$. quadrata at tropical Hole 575A. If this indicated difference in paleogeographic preference is confirmed at other lower Miocene localities, then the biostratigraphic application of Naviculopsis would be linked closely with paleoceanographic interpretations of the assemblages. Whole-assemblage taxonomy and $T S$ calculation may be needed to help define the lower Miocene Naviculopsis stratigraphy (see the section on Silicoflagellate $T s$ Comparison).

\section{Naviculopsis ponticula Zone}

At Hole 575A, the Naviculopsis ponticula Zone is identified by the range of $N$. ponticula. $N$. ponticula spinosa is the dominant Naviculopsis at the top of the zone, but maximum numbers of $N$. ponticula occur in the lower part of the zone. $N$. ponticula is missing in the middle part of the zone, where the Naviculopsis population is dominated sequentially by $N$. obtusarca and $N$. contraria (Table 3). A similar distribution was recorded off Guatemala in the $N$. ponticula Zone of DSDP Site 
Table 2. Early Miocene silicoflagellate biostratigraphy, relative paleotemperature values (Ts), and percent distribution of various genera and morphologic subgroups, with remarks on significant occurrences for Hole 575A.

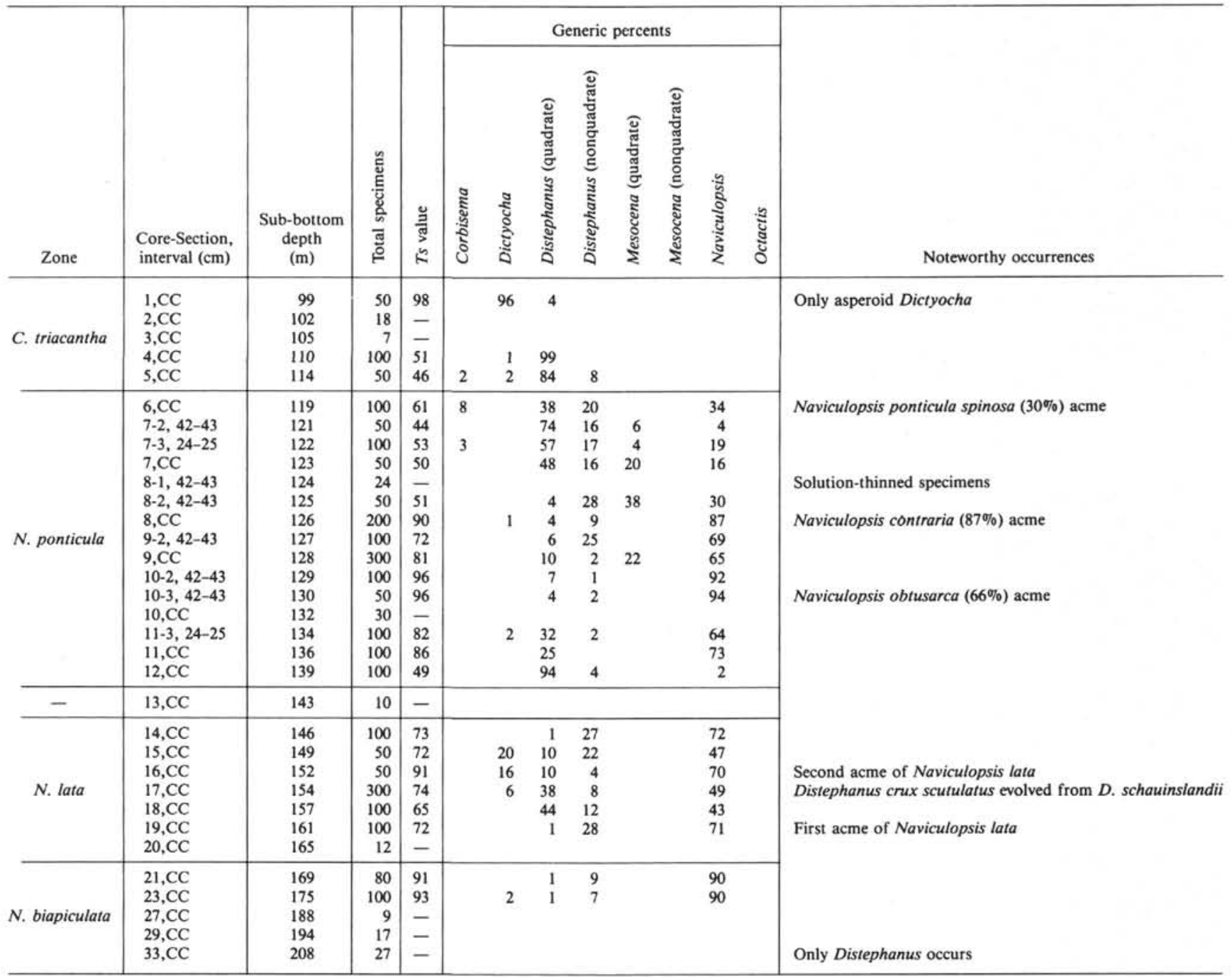

Note: Species distribution for Hole 575A is shown in Table 3. The top of Hole 575A in Core 1 is older by about $1 \mathrm{~m} . \mathrm{y}_{\mathrm{.}}$ than the base of Hole 572D, according to diatom and paleomagnetic correlation (John Barron, personal communication, 22 Aug. 1983).

495 (Bukry, 1982a). The two stratigraphic sequences differ in the presence of an N. lacrima acme horizon at Site 495 and the greater abundance of $N$. ponticula near the top of the zone at Hole 575A. There is an unusual positive correlation between the two sites in the exceptionally high abundance of cruxoid Distephanus just above the lower zone boundary $(85 \%$ at Site 495 and $94 \%$ at Hole 575A) and just above the upper zone boundary $(83 \%$ at Site 495 and $84 \%$ at Hole 575A). Mesocena elliptica var. rhomboidea, n. var. is also essentially limited to the zone at both sites. These distinctive silicoflagellate stratigraphic similarities and the fast plate-tectonic spreading in the region of Site 495 and Hole 575A (van Andel and Bukry, 1973) suggest that Sites 495 and 575 were in much closer proximity during the early Miocene.

\section{Corbisema triacantha Zone}

Corbisema triacantha is sparse and sporadic at Hole $575 \mathrm{~A}$, but the extinction of Naviculopsis, defining the base of the Corbisema triacantha Zone, is distinct. Preservation and diversity deteriorate upward through the zone. Sample 575A-1,CC (Table 3), the highest sample studied from Hole $575 \mathrm{~A}$, is dominated by Dictyocha brevispina ausonia, and contains sparse specimens of Dictyocha pons, which marks a short interval just above the Naviculopsis ponticula Zone at DSDP Hole 416A off northwest Africa (Bukry, 1980a). No deflandroid Dictyocha pulchella were recorded at Hole 575A, so the strata assigned to the $C$. triacantha Zone must represent a short interval at the base of the zone. The absence of any Distephanus stauracanthus or well-developed Dictyocha pulchella, which characterize the upper $C$. triacantha Zone at the base of Hole 572D, also support an assignment of the Hole 575A assemblages to the lower part of the zone.

A somewhat higher stratigraphic level within the zone, with more diversity, is preserved in a thick $(116 \mathrm{~m}) \mathrm{sec}-$ tion at Hole 572D. A distinctive acme of short-ranging, 
Table 3. Occurrences (\%) of early Miocene silicoflagellates in samples from Hole 575A.

\begin{tabular}{|c|c|c|c|c|c|c|c|c|c|c|c|c|c|c|c|c|c|c|c|c|c|c|c|c|c|c|c|c|c|c|c|c|c|c|}
\hline Zone & $\begin{array}{l}\text { Core-Section, } \\
\text { interval }(\mathrm{cm})\end{array}$ & $\begin{array}{l}\text { Sub-bottom } \\
\text { depth } \\
\text { (m) }\end{array}$ & 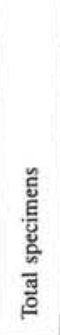 & 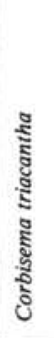 & 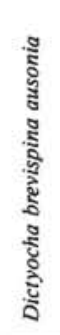 & 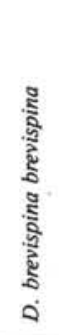 & 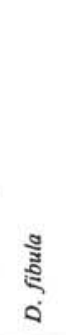 & $\frac{1}{2}$ & 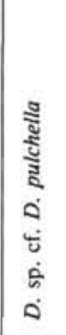 & 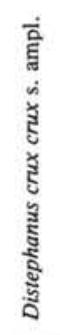 & 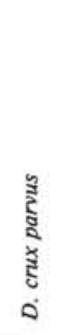 & 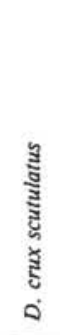 & 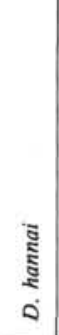 & 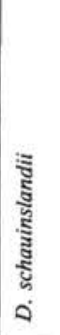 & 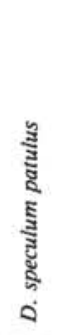 & 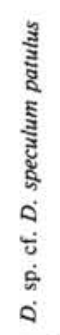 & 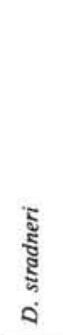 & 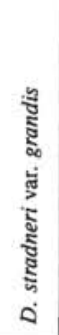 & 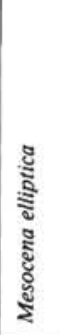 & 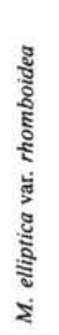 & 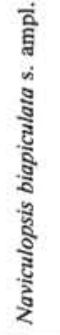 & $\begin{array}{l}\frac{\pi}{5} \\
\frac{5}{8} \\
z\end{array}$ & 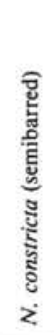 & 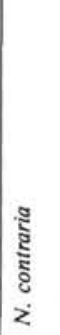 & 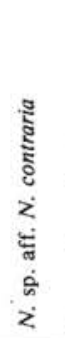 & 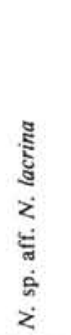 & $\begin{array}{l}\text { ङू } \\
\dot{z}\end{array}$ & 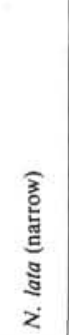 & 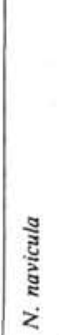 & 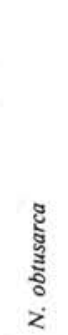 & 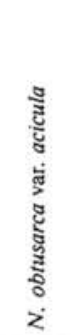 & $\begin{array}{l}\frac{̃}{\tilde{\Xi}} \\
\vdots \\
\vdots \\
z\end{array}$ & 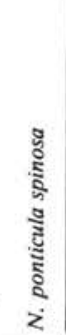 & $\begin{array}{l}\dot{0} \\
\dot{5} \\
\dot{z}\end{array}$ \\
\hline $\begin{array}{l}\text { Corbisema } \\
\text { triacantha }\end{array}$ & $\begin{array}{l}1, \mathrm{CC} \\
2, \mathrm{CC} \\
3, \mathrm{CC} \\
4, \mathrm{CC} \\
5, \mathrm{CC}\end{array}$ & $\begin{array}{r}99 \\
102 \\
105 \\
110 \\
114 \\
\end{array}$ & $\begin{array}{r}50 \\
18 \\
7 \\
100 \\
50 \\
\end{array}$ & $\begin{array}{l}\mathrm{X} \\
2 \\
\end{array}$ & $\stackrel{54}{\otimes}$ & $\begin{array}{l}20 \\
1 \\
2\end{array}$ & $\mathrm{x}$ & 4 & 18 & $\begin{array}{l}4 \\
\times \\
43 \\
70 \\
\end{array}$ & $x$ & $\begin{array}{l}X \\
\otimes \\
56 \\
14 \\
\end{array}$ & $\mathrm{x}$ & & $\begin{array}{r}X \\
8 \\
\end{array}$ & & & & & & & & & & & & & & & & & & & \\
\hline $\begin{array}{l}\text { Naviculopsis } \\
\text { ponticula }\end{array}$ & $\begin{array}{l}6, \mathrm{CC} \\
7-2,42-43 \\
7-3,24-25 \\
7, \mathrm{CC} \\
8-1,42-43 \\
8-2,42-43 \\
8, \mathrm{CC}-4 \\
9-2,42-43 \\
9, \mathrm{CC} \\
10-2,42-43 \\
10-3,42-43 \\
10, \mathrm{CC} \\
11-3,24-25 \\
11, \mathrm{CC} \\
12, \mathrm{CC}\end{array}$ & $\begin{array}{l}119 \\
121 \\
122 \\
123 \\
124 \\
125 \\
126 \\
127 \\
128 \\
129 \\
130 \\
132 \\
134 \\
136 \\
139 \\
\end{array}$ & $\begin{array}{r}100 \\
50 \\
100 \\
50 \\
24 \\
50 \\
200 \\
100 \\
300 \\
100 \\
50 \\
30 \\
100 \\
100 \\
100\end{array}$ & $\begin{array}{l}8 \\
3\end{array}$ & & 2 & & & & $\begin{array}{l}8 \\
4 \\
6 \\
4 \\
3 \\
2 \\
3 \\
4 \\
\\
1 \\
1\end{array}$ & $\begin{array}{l}1 \\
\\
1 \\
2 \\
1 \\
\\
x \\
1 \\
1\end{array}$ & $\begin{array}{c}1 \\
9 \\
4 \\
X \\
28 \\
23 \\
83\end{array}$ & & $\begin{array}{r}2 \\
10\end{array}$ & $\begin{array}{r}20 \\
16 \\
17 \\
16 \\
X \\
28 \\
9 \\
9 \\
25 \\
2 \\
1 \\
2 \\
X \\
2 \\
\\
4\end{array}$ & & 1 & & $\begin{array}{l}6 \\
\times \\
2\end{array}$ & $\begin{array}{r}4 \\
20 \\
X \\
36 \\
\\
22 \\
\\
X\end{array}$ & & 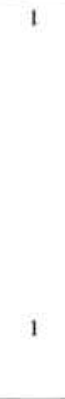 & & $\begin{array}{l}24 \\
87 \\
68 \\
65 \\
75\end{array}$ & & $\begin{array}{r}<1 \\
8\end{array}$ & $\begin{array}{r}\mathrm{X} \\
9\end{array}$ & 1 & 1 & $\stackrel{70}{\otimes}$ & $\begin{array}{r}8 \\
24 \\
X \\
3\end{array}$ & $\begin{array}{r}3 \\
4 \\
19 \\
8 \\
\otimes \\
6\end{array}$ & $\begin{array}{l}30 \\
8\end{array}$ & 8 \\
\hline- & $13, \mathrm{CC}$ & 143 & 10 & & & & & & & $x$ & & $\otimes$ & & & & & & & & & & & & & & & & & & & & & & \\
\hline $\begin{array}{l}\text { Naviculopsis } \\
\text { lata }\end{array}$ & $\begin{array}{l}14, \mathrm{CC} \\
15, \mathrm{CC} \\
16, \mathrm{CC} \\
17, \mathrm{CC} \\
18, \mathrm{CC} \\
19, \mathrm{CC} \\
20, \mathrm{CC}\end{array}$ & $\begin{array}{l}146 \\
149 \\
152 \\
154 \\
157 \\
161 \\
165 \\
\end{array}$ & $\begin{array}{r}100 \\
50 \\
50 \\
300 \\
100 \\
100 \\
12 \\
\end{array}$ & & 2 & $\begin{array}{r}18 \\
16 \\
6 \\
\\
\times\end{array}$ & & & & 1 & & $\begin{array}{r}1 \\
10 \\
10 \\
36 \\
4\end{array}$ & & $\begin{array}{r}2 \\
40\end{array}$ & $\begin{array}{r}27 \\
22 \\
4 \\
8 \\
12 \\
25 \\
X\end{array}$ & $\begin{array}{l}3 \\
\mathrm{x}\end{array}$ & & & & & $\begin{array}{r}33 \\
30 \\
4 \\
34 \\
4 \\
17\end{array}$ & 1 & & 1 & 14 & 1 & $\begin{array}{l}7 \\
48 \\
11 \\
33 \\
40 \\
\otimes\end{array}$ & $\begin{array}{r}23 \\
8 \\
\\
3 \\
6 \\
14\end{array}$ & & & 2 & & & $\begin{array}{l}8 \\
8 \\
2\end{array}$ \\
\hline $\begin{array}{l}\text { Naviculopsis } \\
\text { biapiculata }\end{array}$ & $\begin{array}{l}21, C C \\
23, C C \\
27, C C \\
29, C C \\
33, C C\end{array}$ & $\begin{array}{l}169 \\
175 \\
188 \\
194 \\
208\end{array}$ & $\begin{array}{r}80 \\
100 \\
9 \\
17 \\
27\end{array}$ & & $x$ & $\stackrel{2}{\otimes}$ & & & & $\begin{array}{l}1 \\
1\end{array}$ & & & & & $\begin{array}{r}9 \\
7 \\
\times\end{array}$ & $\underset{x}{\otimes}$ & & $\otimes$ & & & $\begin{array}{r}65 \\
6\end{array}$ & $\begin{array}{l}20 \\
53\end{array}$ & $\begin{array}{r}3 \\
20\end{array}$ & & & & & & & & & & & ${ }_{11}^{2}$ \\
\hline
\end{tabular}

Note: For samples where silicoflagellates are too sparse for meaningful percents, presence $(\mathrm{X})$ and predominance $(\otimes)$ are shown by symbols. See Table 2 for comparisons of relative paleotemperature values ( $T s$ ). 
Table 4. Late and middle Miocene silicoflagellate biostratigraphy, relative paleotemperature values (Ts), and percent distribution of various genera and morphologic subgroups, with remarks on significant occurrences for Hole 572D.

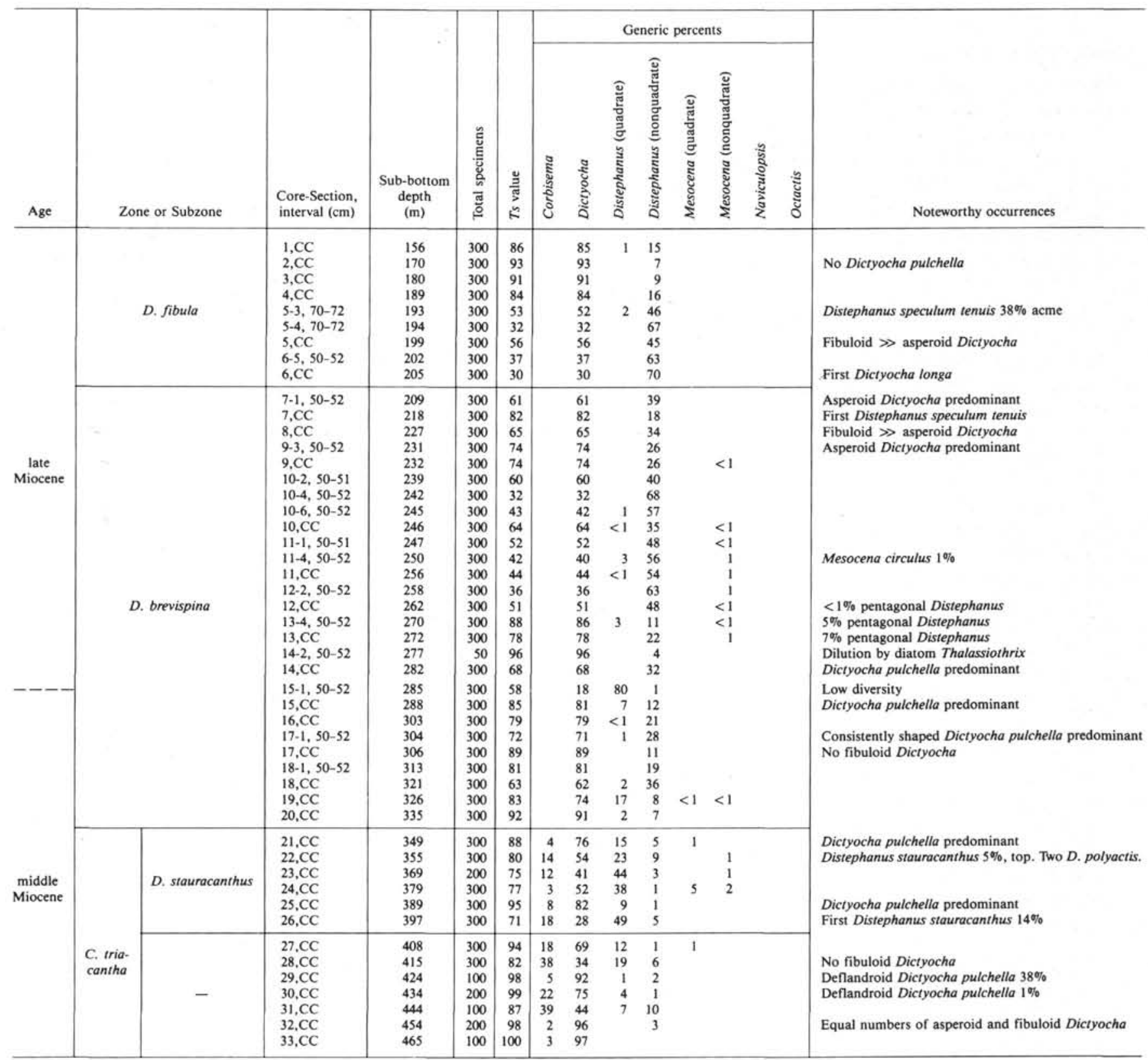

Note: Silicoflagellate data support the correlation between the top of Hole 572D (Core 1) and the base of Hole 572A (Core 17); see Table 5.

deflandroid Dictyocha pulchella in Sample 572D-29,CC accounts for $38 \%$ of the assemblage (Table 4). This value approaches $41 \%$, the maximum recorded, in the Corbisema triacantha Zone of DSDP Site 543 northeast of Barbados in the tropical North Atlantic (Bukry, in press b).

The section at Hole 572D is distinguished by a thick Distephanus stauracanthus Subzone occupying the top $48 \mathrm{~m}$ of the zone. Distephanus stauracanthus is a persistent meager $(5 \%)$ to common $(14 \%)$ member of the assemblages in Cores 572D-22 to 572D-26. An indication that the phenotypic shift from apical ring dominance in early populations of $D$. stauracanthus to apical bar dominance in later populations could be of strati- graphic use for eastern Pacific Site 470 (Bukry, 1981a) is only partly evident at Hole 572D. Ring specimens predominate in Cores 572D-22 and 572D-26 (Plate 3, Fig. 6), whereas bar specimens predominate in the intervening Cores 572D-23 to 572D-25, gainsaying a consistent, oneway shift at this oceanic site.

\section{Dictyocha brevispina Zone}

The assemblages between the extinction of Corbise$m a$ and the appearance of Dictyocha longa are characterized at Hole 572D by low diversity, asperoid-bar dominance within Dictyocha, and the predominance of Dictyocha pulchella among asperoid Dictyocha (often exceeding $90 \%$ ) (Table 4). Aside from a mid-zone cool- 
ing marked by the entry of sparse Mesocena circulus into the assemblages, there are few stratigraphically significant changes.

\section{Dictyocha fibula Zone}

The first Dictyocha longa of Hole 572D defines the base of the Dictyocha fibula Zone and coincides with a locally permanent change from asperoid- to fibuloidbar dominance in Dictyocha (compare Martini, 1971). The lower zonal assemblages of Hole 572D are characterized by low diversity, persistent Distephanus speculum tenuis, the appearance of Dictyocha longa var. paxilla in Sample 572D-2,CC, and the scarcity or absence of D. pulchella in Cores 572D-1 to 572D-3 (Tables 4 and 5). Similar basal assemblages from Cores 16 and 17 of Hole 572A suggest correlation between the two holes at this interval. The best evidence of correlation is the predominance of $D$. longa, presence of $D$. speculum tenu$i s$, and decline of $D$. pulchella. The paleotemperature correlation is also supportive of stratigraphic occurrences.

The lower interval of the zone in Cores 15 to 17 of Hole 572A, below the Dictyocha neonautica Subzone, contains persistent $D$. longa, $D$. longa var. paxilla, and Distephanus speculum tenuis (Table 5). A distinct increase in Distephanus in Core 572A-15 suggests that the stratigraphic appearance of Dictyocha neonautica at the top of the core is related to a cool-water event.

Only two closely spaced samples contain Dictyocha neonautica Subzone assemblages. A possibly compressed section is indicated by the dominance of $D$. neonauti$c a$, which characterizes the lower part of the subzone, in Sample 572A-15-1, 68-69 cm, and by the contrasting dominance of younger $D$. neonautica var. cocosensis, just above in Sample 572A-14,CC. Both samples contain fibuloid Dictyocha, but the asperoid D. brevispina/ $D$. pulchella group is very sparse $(<1$ to $3 \%)$. This relationship suggests that $D$. neonautica filled the asperoid niche at Hole 572A.

The Dictyocha pulchella Subzone is not well defined at Hole 572A, because of the sporadic and sparse occurrence of Dictyocha pulchella. D. brevispina predominates among asperoid Dictyocha.

Dictyocha angulata, a guide fossil for the Dictyocha angulata Subzone, occurs in Cores 7, 9, and 10 of Hole $572 \mathrm{~A}$, but is most abundant at the top of the subzone in Core 7. A minor, rarely encountered species, Dictyocha orbiculata, occurs only in Sample 572A-7,CC (Table 5). This provides a local horizon correlation with Sample 77B-6-5, 100-101 cm, where D. orbiculata was first described (Ling, 1977).

Fibuloid Dictyocha species, including $D$. longa var. paxilla, $D$. perfecta, and $D$. perlaevis, dominate the assemblages at the top of the $D$. fibula Zone in Cores $572 \mathrm{~A}-6$ and $572 \mathrm{~A}-7$. No particular morphologic type is diagnostic for this interval between the last $D$. angulata and the first $D$. flexatella and $D$. ornata africana or $D$. ornata ornata.

\section{Dictyocha stapedia stapedia Zone}

The late Pliocene silicoflagellate guide species Dictyocha flexatella and the D. ornata group (Bukry, 1982a) occur in close order in Samples 572A-6-1, 66-67 cm and $572 \mathrm{~A}-5, \mathrm{CC}$, and indicate the base of the Dictyocha ornata ornata Subzone. Early Dictyocha stapedia stapedia, which first occurs in Sample 572A-6-3, 66-67 cm, is a consistent member of assemblages in Sample 572A-6-1, $66-67 \mathrm{~cm}$ and above. The $D$. ornata group is sparse and sporadic, but the companion species $D$. flexatella is more ubiquitous, although it is abundant (37\%) only in Core 572A-5 (Table 5). Dictyocha calida calida and Distephanus mesophthalmus occur in the top sample of the $D$. ornata ornata Subzone. A similar occurrence in Sample 157-11, CC, recovered to the east, has the conjunction of these two species plus $D$. ornata africana, signifying the stratigraphic potential of short-term conjunctions for correlation in the eastern equatorial Pacific. Both samples are assigned to the highest coccolith subzone of the upper Pliocene (CN12d).

The Dictyocha delicata Subzone of the D. stapedia stapedia Zone is identified in the lower part of Core 572A-3. Because Octactis pulchra is present in this interval with Dictyocha delicata, a Quaternary assignment is made. Minor occurrences of Mesocena quadrangula in the subzone presage the consistent presence of this species above, in the Mesocena quadrangula Zone.

\section{Mesocena quadrangula Zone}

The common occurrence of Mesocena quadrangula above the range of Dictyocha delicata defines the $M$. quadrangula Zone in Cores 2 and 3 of Hole 572A. Dictyocha stapedia stapedia is abundant, but $D$. aculeata is absent or sparse up to Sample 572A-2-3, 68-69 cm, where D. aculeata constitutes a third of the assemblage though D. stapedia stapedia $(47 \%)$ still predominates.

\section{Dictyocha aculeata Zone}

At Hole 572A, Dictyocha aculeata is present throughout the Dictyocha aculeata Zone, but diversity is very low, and, aside from Sample 572A-1-5, 68-69 cm, $D$. stapedia stapedia predominates. Solution-thinning and small-sized specimens are most prominent in this zone, suggesting reduced silica and increased solution relative to DSDP Site 425 , which is farther to the east (Bukry, $1980 \mathrm{~b})$, where higher sedimentation rates and fossil diversity are indicated in this zonal interval.

\section{SILICOFLAGELLATE $T s$ COMPARISON}

The lower Miocene silicoflagellate assemblages of DSDP Hole 575A are significant in relative-paleotemperature $(T S)$ studies, especially because of the near absence of Corbisema, the scarcity of Dictyocha, and the high abundance of Naviculopsis. Previous work on Pacific lower Miocene silicoflagellates at DSDP Site 495 had questioned the paleotemperature significance of $\mathrm{Na}$ viculopsis (Bukry, 1982a), because no living relatives or similarly formed taxa survived into the Quaternary and the known fossil record suggested a cosmopolitan range with greater productivity in cool regions. But the generally high abundances of Naviculopsis through the lower Miocene and the displacement of regular Dictyocha species by naviculopsoid $D$. neonautica in the upper Miocene (Hole 572A) show that Naviculopsis and Navicu- 
Table 5. Late Miocene to Quaternary silicoflagellate biostratigraphy, relative paleotemperature values ( $T s)$, and percent distribution of various genera and morphologic subgroups, with remarks' on significant occurrences for Hole 572A.

\begin{tabular}{|c|c|c|c|c|c|c|c|c|c|c|c|c|c|c|c|}
\hline \multirow[b]{2}{*}{ Age } & \multirow{2}{*}{\multicolumn{2}{|c|}{ Zone or Subzone }} & \multirow[b]{2}{*}{$\begin{array}{l}\text { Core-Section, } \\
\text { interval }(\mathrm{cm})\end{array}$} & \multirow[b]{2}{*}{$\begin{array}{l}\text { Sub-bottom } \\
\text { depth } \\
\text { (m) }\end{array}$} & \multirow[b]{2}{*}{ 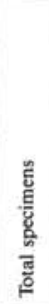 } & \multirow[b]{2}{*}{$\frac{\mathrm{g}}{\mathrm{g}}$} & \multicolumn{8}{|c|}{ Generic percents } & \multirow[b]{2}{*}{ Noteworthy occurrences } \\
\hline & & & & & & & $\frac{\text { है }}{5}$ & $\begin{array}{l}\text { हूँ } \\
\text { : } \\
\text { : }\end{array}$ & 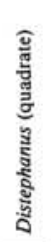 & 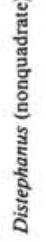 & 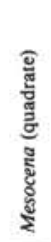 & 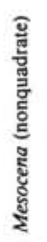 & $\frac{\text { है }}{\text { है }}$ & हूँ & \\
\hline \multirow{3}{*}{ Quaternary } & \multicolumn{2}{|c|}{ D. aculeata } & $\begin{array}{l}1-1,105-106 \\
1-3,67-68 \\
1-5,68-69 \\
1, C C \\
2-1,68-69\end{array}$ & $\begin{array}{r}1 \\
4 \\
7 \\
9 \\
10\end{array}$ & $\begin{array}{l}300 \\
300 \\
300 \\
200 \\
300\end{array}$ & $\begin{array}{r}100 \\
99 \\
99 \\
96 \\
99\end{array}$ & & $\begin{array}{r}100 \\
99 \\
99 \\
96 \\
99\end{array}$ & & & & & & $\begin{array}{l}1 \\
1 \\
4 \\
1\end{array}$ & $\begin{array}{l}\text { D. stapedia stapedia } 98 \% \\
\text { D. aculeata }>\text { D. stapedia stapedia } \\
\text { D. stapedia stapedia } \\
\text { D. stapedia stapedia } 84 \%\end{array}$ \\
\hline & \multicolumn{2}{|c|}{ M. quadrangula } & $\begin{array}{l}2-2,68-69 \\
2-3,68-69 \\
2-4,68-69 \\
2-5,68-69 \\
2-6,68-69 \\
2, C C \\
3-1,68-69 \\
3-2,68-69\end{array}$ & $\begin{array}{l}12 \\
13 \\
15 \\
16 \\
18 \\
19 \\
20 \\
21\end{array}$ & $\begin{array}{l}300 \\
300 \\
300 \\
300 \\
300 \\
300 \\
300 \\
300\end{array}$ & $\begin{array}{l}96 \\
95 \\
87 \\
75 \\
73 \\
71 \\
66 \\
89\end{array}$ & & $\begin{array}{l}94 \\
90 \\
74 \\
54 \\
46 \\
44 \\
35 \\
83\end{array}$ & $<1$ & $\begin{array}{r}2 \\
<1 \\
2 \\
3 \\
2\end{array}$ & $\begin{array}{r}4 \\
10 \\
26 \\
42 \\
53 \\
53 \\
61 \\
12\end{array}$ & & & $\begin{array}{r}2 \\
<1 \\
<1 \\
2 \\
21 \\
1 \\
<1 \\
4\end{array}$ & $\begin{array}{l}\text { D. stapedia stapedia } \\
\text { D. stapedia stapedia } 98 \% \text { of Dictyocha }\end{array}$ \\
\hline & \multirow{2}{*}{ D. stapedia } & D. delicata & $\begin{array}{l}3-3,16-17 \\
3-4,68-69 \\
3-5,68-69 \\
3-6,68-69 \\
3, \mathrm{CC}\end{array}$ & $\begin{array}{l}22 \\
24 \\
26 \\
27 \\
28\end{array}$ & $\begin{array}{l}300 \\
300 \\
300 \\
300 \\
300\end{array}$ & $\begin{array}{l}93 \\
98 \\
92 \\
93 \\
94\end{array}$ & & $\begin{array}{l}88 \\
97 \\
92 \\
93 \\
93\end{array}$ & $\begin{array}{l}<1 \\
<1\end{array}$ & $\begin{array}{l}1 \\
2 \\
8 \\
7 \\
6\end{array}$ & 9 & & & $\begin{array}{r}3 \\
<1 \\
1 \\
<1\end{array}$ & $\begin{array}{l}\text { Dictyocha delicata } 9 \% \\
\text { D. delicata } 23 \% \\
\text { D. delicata } 8 \% \\
\text { D. delicata } 39 \%\end{array}$ \\
\hline $\begin{array}{c}\text { late } \\
\text { Pliocene }\end{array}$ & & D. ornata ornata & $\begin{array}{l}4-3,23-24 \\
4, C C \\
5-3,16-17 \\
5, C C \\
6-1,66-67\end{array}$ & $\begin{array}{l}32 \\
36 \\
39 \\
45 \\
46\end{array}$ & $\begin{array}{l}300 \\
300 \\
300 \\
300 \\
300\end{array}$ & $\begin{array}{l}93 \\
97 \\
91 \\
92 \\
88\end{array}$ & & $\begin{array}{l}88 \\
97 \\
91 \\
92 \\
88\end{array}$ & 10 & $\begin{array}{r}2 \\
3 \\
9 \\
8 \\
12\end{array}$ & & $\begin{array}{l}<1 \\
<1\end{array}$ & & & $\begin{array}{l}\text { Dictyocha calida calida and Distephanus mesophthalmus } \\
\text { Dictyocha flexatella } 4 \% \text {, top } \\
\text { D. Rexatella } 37 \% \text {; no } D \text {. ornata group. } \\
\text { D. brevispina } 1 \% \text {, top. Two } D \text {. ornata africana. } \\
\text { D. flexatella } 1 \% \%\end{array}$ \\
\hline \multirow{4}{*}{$\begin{array}{c}\text { early } \\
\text { Pliocene }\end{array}$} & \multirow{6}{*}{ D. fibula } & - & $\begin{array}{l}6-3,17-18 \\
6-3,66-67 \\
6-5,66-67 \\
6, C C \\
7-2,66-67 \\
7-3,19-20\end{array}$ & $\begin{array}{l}49 \\
50 \\
53 \\
55 \\
57 \\
58\end{array}$ & $\begin{array}{l}300 \\
300 \\
300 \\
300 \\
100 \\
300\end{array}$ & $\begin{array}{l}76 \\
93 \\
79 \\
80 \\
89 \\
93\end{array}$ & & $\begin{array}{l}76 \\
93 \\
79 \\
80 \\
89 \\
92\end{array}$ & $\begin{array}{l}1 \\
2\end{array}$ & $\begin{array}{r}24 \\
7 \\
21 \\
20 \\
10 \\
17\end{array}$ & & $<1$ & & & \multirow{6}{*}{$\begin{array}{l}\text { Dictyocha more equant than elongate, solution thinning } \\
\text { Solution thinning } \\
\text { Dictyocha longa var. paxilla predominant } \\
\text { Low diversity (4 species), no asperoid Dictyocha } \\
\text { No asperoid Dictyocha } \\
\text { Dictyocha angulata }-50 \% \text {, no D. pulchella } \\
\text { Dictyocha orbiculata } 1 \% \\
\text { Small Distephanus speculum speculum } \\
\text { No Dictyocha pulchella, only two asperoid specimens } \\
D \text {. sp. cf. D. angulata } \\
D \text {. sp. cf. D. angulata; small Mesocena circulus. } \\
\text { Only one asperoid Dictyocha } \\
\text { Low diversity }\end{array}$} \\
\hline & & D. angulata & $\begin{array}{l}7-4,66-67 \\
7, C C \\
8-3,16-17 \\
8-3,66-67 \\
8, C C \\
9-3,66-67 \\
9, C C \\
10-3,66-67\end{array}$ & $\begin{array}{l}60 \\
64 \\
67 \\
68 \\
72 \\
76 \\
82 \\
85\end{array}$ & $\begin{array}{l}300 \\
300 \\
300 \\
300 \\
300 \\
300 \\
300 \\
300\end{array}$ & $\begin{array}{l}90 \\
81 \\
58 \\
60 \\
45 \\
61 \\
90 \\
72\end{array}$ & & $\begin{array}{l}90 \\
80 \\
57 \\
59 \\
45 \\
61 \\
87 \\
72\end{array}$ & $\begin{array}{r}1 \\
1 \\
1 \\
<1 \\
6 \\
<1\end{array}$ & $\begin{array}{r}10 \\
19 \\
41 \\
39 \\
43 \\
39 \\
6 \\
18\end{array}$ & & $\begin{array}{r}<1 \\
1 \\
1 \\
12 \\
<1 \\
<1 \\
10\end{array}$ & & & \\
\hline & & - & $\begin{array}{l}10, \mathrm{CC} \\
11-3,67-68 \\
11-5,67-68\end{array}$ & $\begin{array}{l}91 \\
95 \\
98\end{array}$ & $\begin{array}{l}300 \\
300 \\
300\end{array}$ & $\begin{array}{l}56 \\
44 \\
83\end{array}$ & & $\begin{array}{l}51 \\
40 \\
82\end{array}$ & $\begin{array}{r}6 \\
5 \\
<1\end{array}$ & $\begin{array}{l}40 \\
53 \\
18\end{array}$ & $\begin{array}{r}3 \\
3 \\
<1\end{array}$ & & & & \\
\hline & & D. pulchella & $\begin{array}{l}11, \mathrm{CC} \\
12-2,68-69 \\
12, \mathrm{CC} \\
13-3,66-67 \\
13, \mathrm{CC} \\
14-3,18-19\end{array}$ & $\begin{array}{l}101 \\
103 \\
110 \\
114 \\
119 \\
122\end{array}$ & $\begin{array}{l}300 \\
300 \\
300 \\
300 \\
300 \\
300\end{array}$ & $\begin{array}{l}82 \\
67 \\
52 \\
49 \\
52 \\
60\end{array}$ & & $\begin{array}{l}82 \\
66 \\
51 \\
45 \\
48 \\
59\end{array}$ & $\begin{array}{r}<1 \\
2 \\
2 \\
1 \\
2 \\
1\end{array}$ & $\begin{array}{l}17 \\
32 \\
46 \\
47 \\
43 \\
39\end{array}$ & $\begin{array}{l}6 \\
7 \\
1\end{array}$ & & & & \\
\hline \multirow[b]{2}{*}{$\begin{array}{c}\text { late } \\
\text { Miocene }\end{array}$} & & D. neonautica & $\begin{array}{l}14, \mathrm{CC} \\
15-1,68-69\end{array}$ & $\begin{array}{l}128 \\
129\end{array}$ & $\begin{array}{l}300 \\
300\end{array}$ & $\begin{array}{l}74 \\
66\end{array}$ & & $\begin{array}{l}73 \\
66\end{array}$ & 1 & $\begin{array}{l}26 \\
33\end{array}$ & & & & & \\
\hline & & - & $\begin{array}{l}15-3,19-20 \\
15, \mathrm{CC} \\
16-2,66-67 \\
16-3,19-20 \\
16, \mathrm{CC} \\
17, \mathrm{CC}\end{array}$ & $\begin{array}{l}132 \\
137 \\
139 \\
140 \\
145 \\
154\end{array}$ & $\begin{array}{l}300 \\
300 \\
300 \\
300 \\
300 \\
300\end{array}$ & $\begin{array}{l}44 \\
29 \\
71 \\
81 \\
88 \\
84\end{array}$ & & $\begin{array}{l}43 \\
28 \\
71 \\
80 \\
83 \\
83\end{array}$ & $\begin{array}{r}1 \\
2 \\
<1 \\
2 \\
9 \\
2\end{array}$ & $\begin{array}{r}56 \\
69 \\
29 \\
18 \\
8 \\
15\end{array}$ & \multicolumn{4}{|l|}{$<1$} & \\
\hline
\end{tabular}

Note: Silicoflagellate data support the correlation between the base of Hole 572A (Core 17) and the top of Hole 572D (Core 1); see Table 4.

lopsis-like forms occupied a paleotemperature niche similar to that of Dictyocha at tropical Sites 572 and 575.

New Naviculopsis paleotemperature information is indicated by the absence of the stratigraphic guide species Naviculopsis quadrata at Hole 575A. The first $N$. quadrata can be used to distinguish a zonal interval above the N. lata Zone (Bukry, 1981b). To account for its absence, sites at high latitude (Site 338) and low latitude (Site 369 ) in the Atlantic were compared. Naviculopsis quadrata was quantitatively more abundant than $N$. lata at high latitude, whereas at low latitude $N$. lata far outnumbered $N$. quadrata. Therefore, the very high abundances of $N$. lata (up to $48 \%$ ) at Hole $575 \mathrm{~A}$, and the complete absence of $N$. quadrata, show that the distribution of certain species within Naviculopsis can probably be used effectively for relative-paleotemperature comparisons.

Calculation of $T s$ values for Hole 575A yields fluctuations of considerable amplitude in the lower Miocene, with values from Ts 44 to Ts 96 (Fig. 2). Naviculopsis 


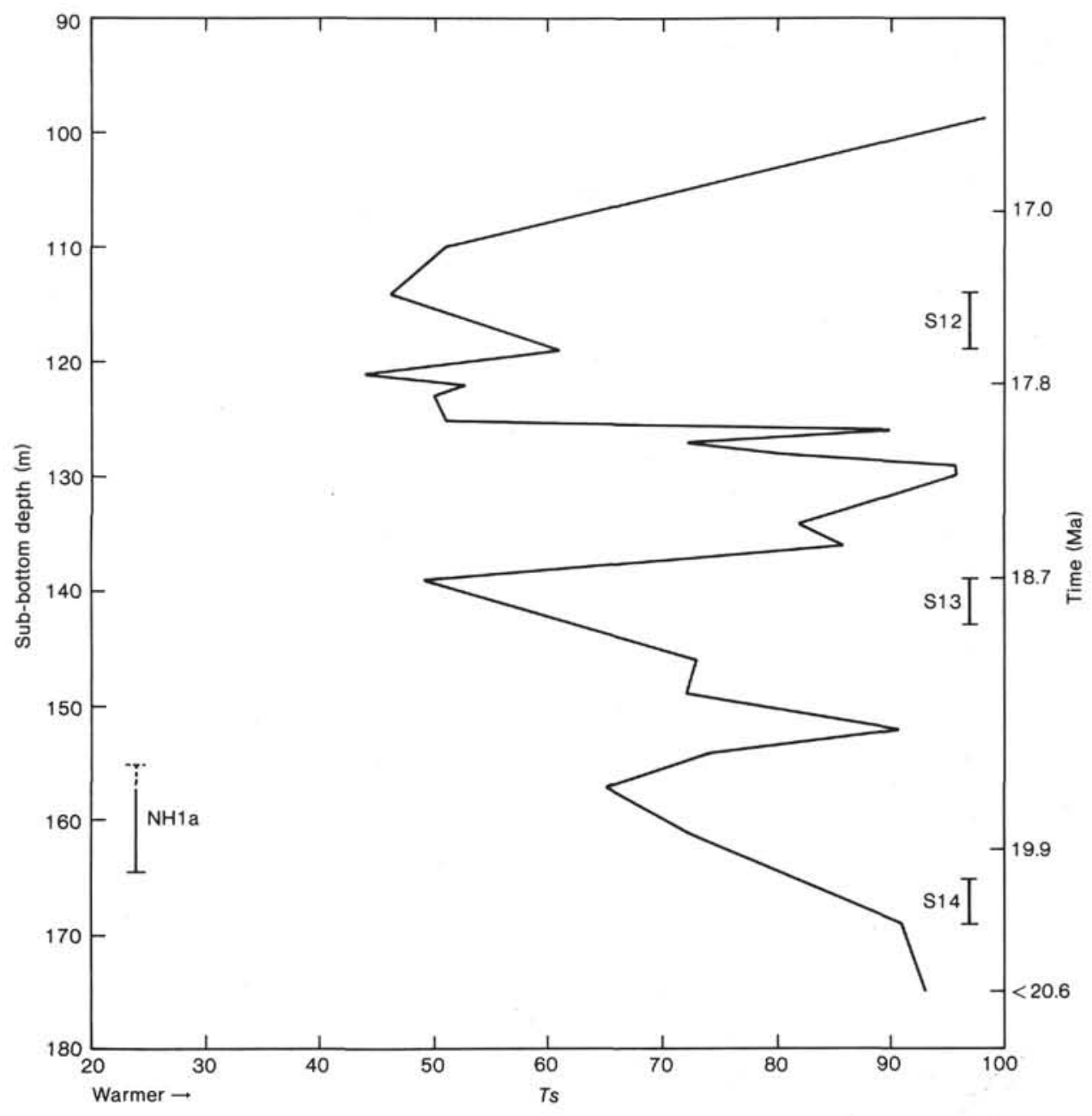

Figure 2. Silicoflagellate relative paleotemperature curve for Hole 575A samples. The chronology shown is based on diatom ages (Ma); see Barron (this volume). Silicoflagellate data for the curve are available in Table 3. Useful silicoflagellate events: $\mathrm{S} 12$ = last Naviculopsis ponticula ponticula; $\mathrm{S} 13=$ first $\mathrm{Na}$ viculopsis ponticula ponticula; $\mathrm{S} 14$ = first Naviculopsis lata. A deep-sea hiatus (NH1a) interval, representing a cool-water event beginning at 20.0 Ma (Keller and Barron, 1983), is shown.

was counted as warm, filling the niche occupied by Dictyocha in younger Neogene strata. Surprisingly, the cool troughs within Cores 7, 12, and 18 of Hole $575 \mathrm{~A}$ are not the levels of maximum abundance for cool-water indicator Distephanus (hexagonal). Instead, these Ts minima are dominated by the temperate-water indicator Distephanus (quadrate). Because the $T s$ paleotemperature model was designed for middle Miocene and younger assemblages (Bukry, 1981a), it is possible that the paleotemperature significance of older species in the genera cited was not the same. In other words, Oligocene and early Miocene Distephanus (quadrate) could have been an indicator of cool water, instead of temperate, whereas $\mathrm{Di}$ stephanus (hexagonal) could have been a temperate- and not a strictly cool-water indicator. There is some evidence supporting such a paleotemperature transition, beyond the record at Hole $575 \mathrm{~A}$, in the abundances of Distephanus (quadrate versus hexagonal) at different latitudes during the Oligocene and early Miocene. Quadrate specimens equal or outnumber the hexagonal at highlatitude DSDP Holes 173, 267, 274, 278, 280A, 328B,
338, and 407. Hexagonal specimens of Distephanus achieved continuing dominance over quadrate first at higher-latitude sites, such as Site 278 (Bukry, 1975) in the early Miocene, and somewhat later at lower-latitude sites, such as nearshore Site 470 in the late Miocene and offshore Hole 572D in the late middle Miocene (see Table 4). Therefore, hexagonal Distephanus can be the cool-water indicator for the late Miocene to Holocene, but for the Oligocene and part of the early Miocene, quadrate Distephanus and probably Mesocena may be the better cool-water indicators.

Corbisema has been used as a warm-water indicator because of its great abundance during the Paleocene and Eocene thermal highs and subsequent extinction at the beginning of a sharp thermal drop in the middle Miocene (see Shackleton, 1982). However, the last few species of the genus in the Miocene are nearly absent at tropical Hole 575A. The record and abundance at Hole 572D are better, with some values almost as high as the $58 \%$ recorded at Site 407 between Iceland and Greenland. Other high abundances of C. triacantha appear to 
occur at temperate coastal sites, such as DSDP Sites 415 and 470 (Bukry, in press b), where the maximum values are 48 and $23 \%$, respectively. By contrast, the values for Corbisema at cool-water sites such as DSDP Sites 173 and 278 are very low, from 0 to $12 \%$ and from 0 to $3 \%$, respectively. Also, at DSDP Site 407 , up to $17 \%$ of the Corbisema specimens belong to C. flexuosa, which is also present at high-latitude Site 278 but missing at most low- or mid-latitude sites.

Although temperature seems to affect the abundance of Corbisema, other fertility-enhancing conditions, such as nitrogen or phosphorus enrichment, must have contributed to the high abundances at Sites 407 and 415 in the Atlantic.

A major cooling of $T s$ relative-paleotemperature values in the lower Miocene of Hole 575A occurs from the middle of the Naviculopsis ponticula Zone up into the lower Corbisema triacantha Zone in Cores 4 to 9. This cool portion of the Ts curve corresponds to an interval of increased foraminifer dissolution (see Fig. 2 and site chapter for Site 575) and deep-sea hiatus NH1b (Barron and Keller, 1982; Keller and Barron, 1983). The association of effects suggests a global cooling event corresponding to a level near the extinction of Naviculopsis at the base of the Corbisema triacantha Zone.

Quadrate Distephanus have two levels of maximum abundance in the lower Miocene at Holes 575A and 495. The samples just above the base of the Naviculopsis ponticula Zone and just above the top have the highest percentages (84 to $99 \%$ ) recorded for quadrate Distephanus at Hole 575A. At Site 495, the sampling interval was less detailed, but a similar occurrence pattern for quadrate Distephanus is recorded, showing the highest percentages ( 81 and $82 \%)$ at the boundaries of the $N$. ponticula Zone.

The Ts relative-paleotemperature curves for the $\mathrm{Na}$ viculopsis ponticula Zone at Holes 575A and 495 show the same major trends (Figs. 2 and 3). There are cool values of $T s=49$ to 53 for the upper and lower parts of the zone, bracketing a pronounced warm peak ( $T S=88$ to 96) in the middle. This close correspondence between biostratigraphic and paleotemperature records at Holes $575 \mathrm{~A}$ and 495 indicates a much closer proximity of these sites or much more uniform conditions in the eastern Pacific during the early Miocene.

Oxygen-isotope thermometry from benthic foraminifers shows a steep decline in paleotemperatures of world oceans from about $15 \mathrm{Ma}$ to $8 \mathrm{Ma}$ (Shackleton, 1982). The long-term record of silicoflagellate relative-paleotemperature values, $T s$, for Holes 572A and 572D encompasses the last $15 \mathrm{~m}$.y. of the Cenozoic and shows a fluctuating decline (major cool events progressively cooler) from about $15 \mathrm{Ma}$ to $7 \mathrm{Ma}$, followed by a fluctuating increase (major cool events progressively warmer) after 7 Ma (Figs. 4 and 5). Within the interval of declining paleotemperature, from the Corbisema triacantha Zone to the lower Dictyocha fibula Zone, there was a lower part below $321 \mathrm{~m}$ sub-bottom where lower-amplitude fluctuations prevailed, principally in the $C$. triacantha Zone. The upper part of the decline, mainly within the $D$. brevispina Zone, has higher-amplitude fluctuations, as the coolest points diverge further from the intervening warm points.

Comparison of the upper part of the Ts curve for Hole 572D to that for Hole 503A (farther east) shows corresponding cool points at about $7.3 \mathrm{Ma}$ and warm points at 6.0 to $6.1 \mathrm{Ma}$. The $T s$ values of these warm points are in close agreement at $T s=93$ and $T s=97$, respectively. But the cool point at Hole $572 \mathrm{D}(T s=30)$ is considerably cooler than the coeval point at Hole 503A $(T s=67)$, suggesting a greater westward-versus northward-vector of Peru Current waters or related systems. The paleotemperature contrast is evidenced by the $70 \%$ abundance of hexagonal Distephanus for Hole 572D, versus only $29 \%$ for Hole $503 \mathrm{~A}$. This paleotemperature contrast between the oceanographic regimes at the two

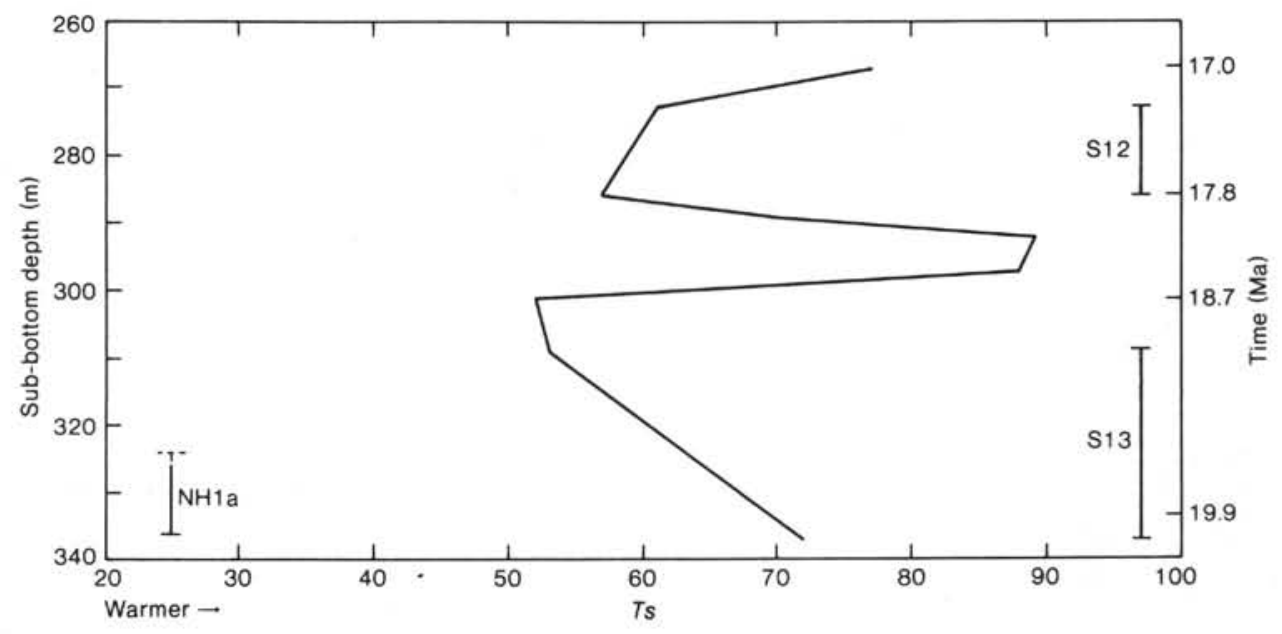

Figure 3. Silicoflagellate relative paleotemperature curve for Hole 495 samples. The chronology shown is based on diatom ages (Ma); see Barron (1983 and this volume). Silicoflagellate data for the curve are available in Bukry (1982a). Useful silicoflagellate events: $\mathrm{S} 12$ = last Naviculopsis ponticula ponticula; $\mathrm{S} 13$ = first Naviculopsis ponticula ponticula. A deep-sea hiatus (NH1a) interval, representing a coolwater event beginning at $20.0 \mathrm{Ma}$ (Keller and Barron, 1983), is shown. 
D. BUKRY

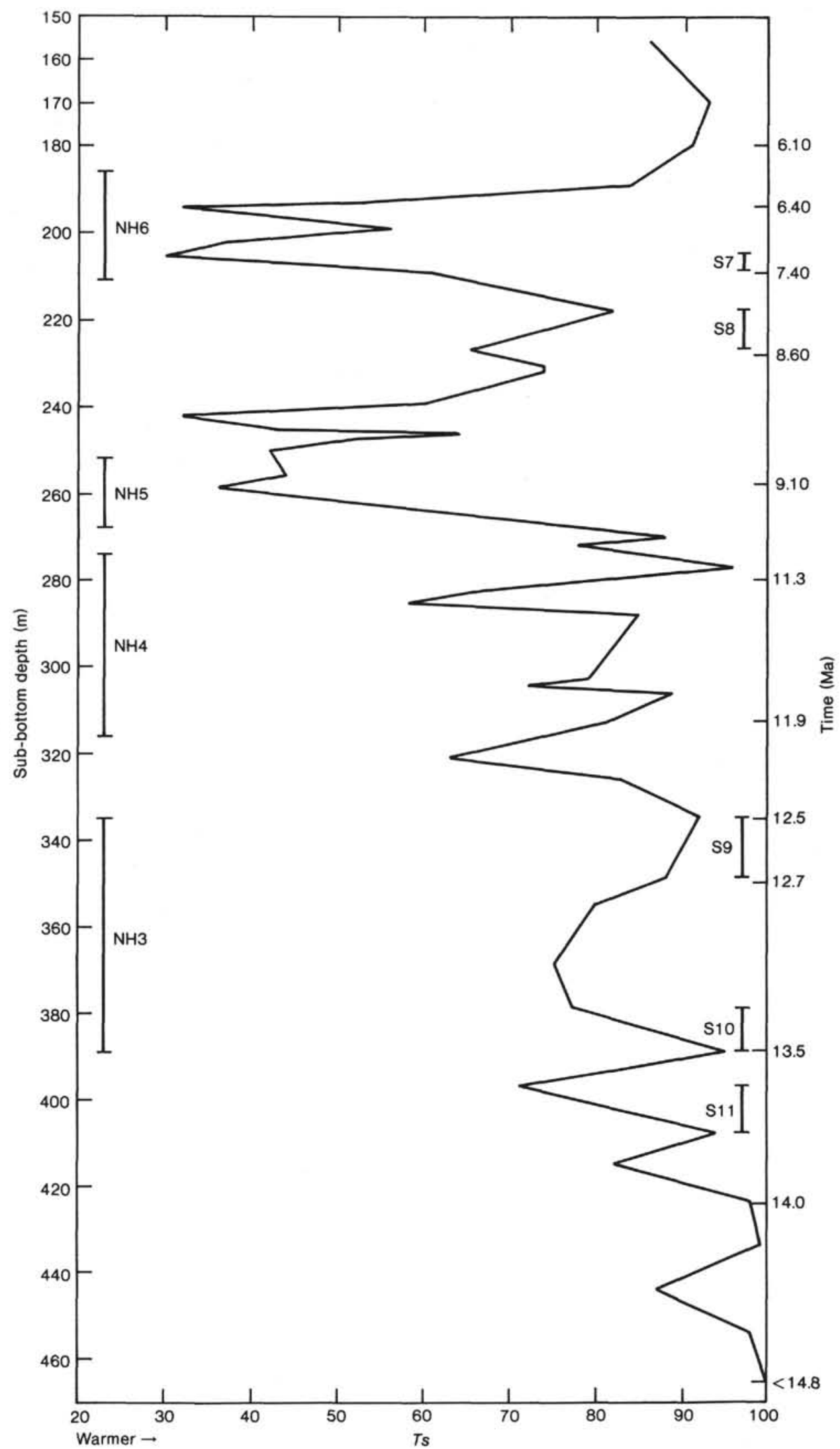

Figure 4. Silicoflagellate relative paleotemperature curve for Hole 572D samples. The chronology shown is based on diatom ages (Ma); see Barron (this volume). Silicoflagellate data for the curve are available in Table 4. Useful silicoflagellate events: S7 = first Dictyocha longa; $\mathbf{S 8}=$ first Distephanus speculum tenuis; $\mathrm{S} 9=$ last Corbisema triacantha $; \mathrm{S} 10=$ first Mesocena circulus; $\mathrm{S} 11=$ first Distephanus stauracanthus. Deep-sea hiatus (NH3 to NH6) intervals, representing cool-water events (Keller and Barron, 1983), are shown. 


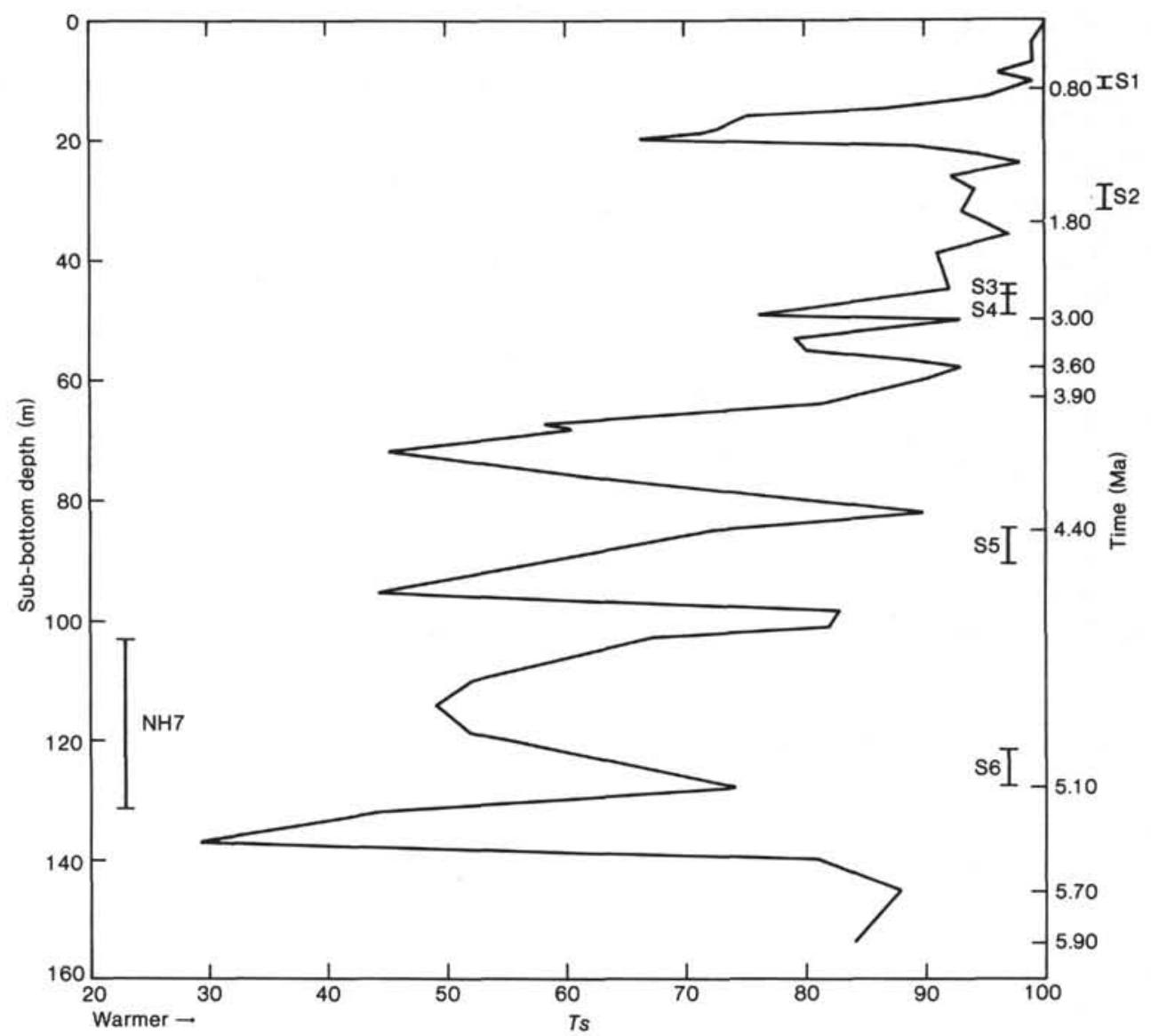

Figure 5. Silicoflagellate relative paleotemperature curve for Hole 572A samples. The chronology shown is based on diatom ages (Ma); see Baldauf (this volume) and Barron (this volume). Silicoflagellate data for the curve are available in Table 5. Useful silicoflagellate biostratigraphic events: $\mathrm{S} 1$ = last Mesocena quadrangula; $\mathrm{S} 2=$ first Octactis pulchra; $\mathrm{S} 3=$ first Dictyocha ornata africana; $\mathrm{S} 4=$ first Dictyocha stapedia stapedia $;$ S5 = first Dictyocha angulata; S6 = last Dictyocha neonautica var. cocosensis. A deep-sea hiatus (NH7) interval, representing a cool-water event or events between 4.7 and $5.2 \mathrm{Ma}$ (Keller and Barron, 1983), is shown.

locations persisted for a considerable period because coolwater indicator Mesocena circulus is recorded at Hole 572D but missing from Hole 503A.

The Miocene/Pliocene boundary warm peak (about $5.0 \mathrm{Ma}$ ) is present at Holes $572 \mathrm{~A}$ and $503 \mathrm{~A}$, but like the 6.0-Ma warm peak the Hole $572 \mathrm{~A}$ assemblage yields a cooler $(T s=74)$ value than that of Hole 503A (Ts = 92). A nearly 20-point difference is also seen for the Dictyocha pulchella/Dictyocha angulata cool peak at about $4.5 \mathrm{Ma}$ in Core 11 of Hole $572 \mathrm{~A}(T s=44)$ and Cores 24 to 27 of Hole 503A ( $T s=68$ ). The following Dictyocha angulata warm peak ( 3.4 to $3.8 \mathrm{Ma}$ ) occurs in the middle of Core 7 of Hole 572A, and the Ts value of 93 is nearly identical to the correlative Ts value of 97 for Hole 503A. Above this level the values are very similar. Therefore, between 7.3 and $3.8 \mathrm{Ma}$ the $T S$ values at Hole $572 \mathrm{~A}$ gradually changed from much cooler $(\Delta 37)$ to cooler $(\Delta 24)$ to nearly identical $(\Delta 4)$, at fairly high values in the 80 s and $90 \mathrm{~s}$. A weakening of the westward component of the Peru Current, combined with the oceanic effects resulting from the closing of the Panamani- an Land Bridge, could have contributed to this convergence of relative-paleotemperature records.

A possibly analogous modern feature is the eastern equatorial tongue of cool surface waters, below $21^{\circ} \mathrm{C}$, that in July and August extends as far west as Site $\mathbf{5 7 2}$ (Bernstein and Morris, 1983). The tongue is maintained by westward advection of cool water from coastal South America and by locally wind-driven equatorial upwelling (Bernstein and Morris, 1983). Site 503 lies slightly north of this cool tongue, in the latitudinal band of warmest temperatures, where isotherms are compressed and rise as high as $27^{\circ} \mathrm{C}$. Shifting of these temperature zones in response to oceanographic changes could be responsible for the exceptional contrast in cool and warm values portrayed by the $T s$ relative-paleotemperature curve.

Above the Dictyocha angulata warm peak, the high amplitudes ( $T s=\Delta 30$ to $\Delta 50$ ) of the upper Miocene and lower Pliocene relative-paleotemperature fluctuations at Hole $572 \mathrm{~A}$ are remarkably diminished to amplitudes of less than $T s=\Delta 24$, typically less than $T s=\Delta 5$. The 
major event in the upper Pliocene and Quaternary is the acme and extinction of Mesocena quadrangula at about $1 \mathrm{Ma}$. Although the acme of $M$. quadrangula occurs at low latitude and is missing at high latitude, the paleotemperature character of $M$. quadrangula is considered to be temperate at low latitude because an upper Miocene bloom of this species coincides with locally elevated numbers of cool-water Distephanus speculum speculum at DSDP Sites 157 and 504. This supports the presumption that later occurrences of the same morphology reflect similar temperature trends.

Owing to a general decline of cool-water indicator $D$. speculum speculum in the Quaternary of tropical areas, $M$. quadrangula is thought to indicate relatively cool or temperate paleotemperatures. The few $D$. speculum speculum at Hole 572A in the $M$. quadrangula acme have a distribution of 2 specimens and 5 specimens just below the acme, 9 specimens at the acme, and 5 specimens, followed by 0 specimens, above, in the interval of the decline of $M$. quadrangula to extinction.

The coolest value ( $T s=66$ ) for the Quaternary is assigned to the Mesocena quadrangula acme at Hole 572A. Correlative $M$. quadrangula acme $T s$ values are $T s=65$ at Site 157 and $T S=63$ at Site 504. Silicoflagellates indicate close similarity in paleotemperature response for the eastern tropical Pacific region at that time.

In the Atlantic, an especially cool event, producing $63 \% \mathrm{D}$. speculum speculum, coincides with a reduced acme of $M$. quadrangula at Site $397(T s=28)$. Just above the acme at Site 397, the value is more similar to that for the Pacific, at $T S=69$ (Bukry, 1979b).

The general trend of the upper Cenozoic eustatic sealevel curve, constrained by Midway Island stratigraphy (Major and Matthews, 1983), shows a long-term decline for the Pacific between 13 and 6.7 Ma. Although the Midway evidence reduces the amplitudes of eustatic sealevel fluctuation (Major and Matthews, 1983), the principal times of rapid change of sea level (Vail et al., 1977) are corroborated. The end of a highstand of sea level at about $13 \mathrm{Ma}$ corresponds to a warming trend ( $T s=76$ to 92) on the silicoflagellate relative-paleotemperature curve for Cores 572D-23 to 572D-20, at the base of the Dictyocha brevispina Zone. A sharp decline in Ts values from $T s=96$ to $T s=36$ occurs between about 11.3 and 10.7 $\mathrm{Ma}$, and is the first major cooling event within the late Miocene. This was also the time of one of the maximum declines of eustatic sea level at about $11 \mathrm{Ma}$, and indicates that marine temperature response (measured by silicoflagellate $T s$ ) to rapid sea-level changes is similarly rapid.

After the maximum lowering at about $6.7 \mathrm{Ma}$, the eustatic sea level has an average upward trend that is overlain by higher-frequency oscillations. The general average trend for $T s$ values is also inflected upward between 6 and $7 \mathrm{Ma}$ toward warmer $T s$ values at Site 572 . A broad warming across the Miocene/Pliocene boundary has been shown by $T s$ values for Holes 503A and 504 in the eastern Pacific and for Hole 552A in the North Atlantic. At Hole 572A this warming is abbreviated near a stratigraphically compressed section that re- duced the upper and lower Dictyocha neonautica Zone to a short 1-m section.

Correlations between the Pliocene and Pleistocene eustatic sea-level fluctuations and Ts fluctuations are less positive than for the Miocene. The sea-level decline at about $3.0 \mathrm{Ma}$ is distinguished as a major event comparable to the maximum lowering at $6.7 \mathrm{Ma}$. Many biostratigraphic events, such as the first Dictyocha flexatel$l a$ and D. ornata africana, occur at about $3.0 \mathrm{Ma}$. It is one of the last times of depressed $T s$ values $(T S=76)$ at Hole 572A, following the Dictyocha angulata warm peak $(T s=93)$.

Comparison of the $T s$ relative-paleotemperature curve of silicoflagellates to the sequence of Neogene deep-sea hiatuses (Barron and Keller, 1982; Keller and Barron, 1983) shows good correlation between cool $T s$ minima and hiatus intervals such as NH1a, NH3, NH6, and NH7 (Figs. 2 to 5). Also, some of the major declines in Pacific eustatic level (Major and Matthews, 1983) occur at the same times as Ts minima and deep-sea hiatuses, such as NH3 and Eustatic Event (EE) 1 after $13 \mathrm{Ma}$, and NH6 and EE3 at about 6.7 Ma (Fig. 4). The rising sea level at EE5 correlates with the warming $T s$ values from about 5.2 Ma to 5.1 Ma at Hole 572A (Fig. 5). Such correlations suggest that paleoceanographic changes linking cool paleotemperatures, lowered sea levels, and deep-sea hiatuses may be detected in the $T s$ relative-paleotemperature record of shallow-dwelling siliceous phytoplankton such as silicoflagellates.

The paleoecologic signal to be derived from absolute and relative comparisons of silicoflagellate $T s$ values is significant enough to consider such information a useful addition to other chemical and physical measures for paleoceanography. The silicoflagellate photosynthetic habitat in surface waters and the temperature-sensitive variation in generic proportions make silicoflagellates valuable indicators for changes in marine paleotemperature in areas where their productivity has been sufficient.

\section{SYSTEMATIC PALEONTOLOGY OF NEW TAXA \\ Genus DICTYOCHA Ehrenberg, 1837 \\ Dictyocha nola Bukry, n. sp. \\ (Plate 2, Figs. 1-5)}

Description. Dictyocha nola has a moderate-sized, generally wide, oblong basal ring with slightly protruding minor-axis portals and short spines. The outer margins of portals are squared off, and the basal pikes are close to the strut junctions. The short to moderate apical bar is oriented along the minor axis of the basal ring. A few specimens have apiculate basal rings or lack minor-axis spines.

Remarks. Dictyocha nola is distinguished from other taxa with the same structural elements, such as Dictyocha brevispina ausonia, $D$. brevispina brevispina, and $D$. pulchella, by a combination of different proportions. The flattened ends of the major-axis portals (resembling the top of a large bell) and the subparallel sides of the portal yield an oblong outline missing in the other taxa. The larger, protruding, minor-axis portals and basal pike location distinguish $D$. nola from $D$. brevispina ausonia. The other asperoid taxa have a more rhomboid than oblong outline. The squared-off portals of $D$. nola are an effect similar to that seen in the smaller, fibuloid species $D$. angulata, which occurs just above $D$. nola in Cores 7 to 10 of Hole $572 \mathrm{~A}$.

Occurrence. Dictyocha nola accounts for $20 \%$ of the Dictyocha specimens in Sample 572A-11-3, 67-68 cm (95 m), which is assigned to the lower Pliocene Dictyocha fibula Zone, between 4.40 and $5.10 \mathrm{Ma}$, 
according to diatom ages. It was not identified in other samples, and may represent a useful, short-lived, horizon species.

Size. Maximum inner diameter 25 to $33 \mu \mathrm{m}$ (holotype $31 \mu \mathrm{m}$ ).

Holotype. USNM 371373 (Plate 2, Fig. 3).

Isotypes. USNM 371374 to 371377 .

Type locality. Eastern equatorial Pacific, Sample 572A-11-3, 67-68 cm (95 m sub-bottom).

\section{Genus DISTEPHANUS Stöhr, 1880 \\ Distephanus stradneri (Jerkovíc) Bukry \\ var. grandis Bukry, n. var.}

(Plate 4, Figs. 1-7)

Description. Distephanus stradneri var. grandis has a large, elongate-rhomboid basal ring and a small, slightly oblong apical ring, connected together by symmetric struts. The major-axis spines are two to four times the length of the minor-axis spines, but all spines are short. Minor-axis portals are less angular than major-axis portals because of rhomboid elongation. Elongation, measured by the ratio of majorand minor-axis inner diameters, ranges from 1.13 to 1.29 , and the outer-diameter ratio (including spines) ranges from 1.30 to 1.44 . Some specimens show small basal pikes next to the strut junctions.

Remarks. Distephanus stradneri var. grandis is distinguished from D. stradneri, including D. pusillus (see Bukry, 1982a), by the rhomboid elongation of the basal ring, shown by the inner-diameter ratio, which is higher (1.13 to 1.29 , average 1.16$)$ for $D$. stradneri var. grandis and lower $(1.00,1.04$, and 1.08$)$ for D. stradneri (including D. pusillus). The small pikes present on some $D$. stradneri var. grandis are absent on $D$. stradneri. The short spines may also help to distinguish $D$. stradneri var. grandis.

Occurrence. Distephanus stradneri var. grandis occurs in the lower Miocene Naviculopsis biapiculata Zone, Core 33 of Hole 575A. Ling (1977) illustrated a square-ringed $D$. stradneri from the lower Miocene of the eastern Pacific, which also has short spines but is slightly older than $D$. stradneri var. grandis, according to diatom correlations (Barron, 1983 and this volume), and which is probably a lineal source of the elongate evolution evidenced by $D$. stradneri var. grandis.

Size. Maximum inner diameter 35 to $45 \mu \mathrm{m}$ (holotype $41 \mu \mathrm{m}$ ).

Holotype. USNM 371378 (Plate 4, Fig. 2).

Isotypes. USNM 371379 to 371384 .

Type locality. Eastern equatorial Pacific, DSDP Sample 575A-33,CC (208 m sub-bottom)

\section{Genus MESOCENA Ehrenberg, 1843 \\ Mesocena elliptica (Ehrenberg) Ehrenberg var. rhomboidea Bukry, n. var.}

(Plate 5, Figs. 1-6)

Mesocena elliptica (Ehrenberg), Bukry, 1978a, p. 698, pl. 2, fig. 16.

Description. Mesocena elliptica var. rhomboidea has a straightsided, elongate, rhomboid-shaped basal ring with angular corners and four short, nearly equal spines at the corners. The elongation of the basal ring, measured by the ratio of major and minor axes, ranges from 1.2 to 1.5 , with an average of 1.4.

Remarks. Mesocena elliptica var. rhomboidea is distinguished from Mesocena elliptica (see Ehrenberg, 1840, 1854) by its rhomboid basal ring with straight sides, instead of curved, elliptic, or oval basal ring. It is distinguished from Mesocena quadrangula by having an elongate rhomboid ring, instead of a square ring. M. elliptica var. rhomboidea is classified with $M$. elliptica because of short, nearly equant spines and stratigraphic similarities.

Locker's (1974) designation of a rhomboidal lectotype for $M$. elliptica is considered superfluous because Ehrenberg described $M$. elliptica as an elliptic form from Zante, Greece (Ehrenberg, 1840) and illustrated a group of elliptic specimens from Zante, Greece (Ehrenberg, 1854). Therefore, Ehrenberg's species concept was adequately fixed in the last century. Designation of Ehrenberg's (1854) pl. 20, fig. $44 \mathrm{~b}$ as the lectotype for $M$. elliptica is preferred to the subsequent rhomboid specimen illustrated in 1974 by Locker.

Occurrence. Mesocena elliptica var. rhomboidea occurs in the lower Miocene Naviculopsis ponticula Zone in Cores 7 to 10 of DSDP Hole $575 \mathrm{~A}$ in the Pacific and in Core 3 of DSDP Hole 370 in the Atlantic. It occurs below and with $M$. elliptica sensu Ehrenberg at DSDP Hole 575A. Therefore, the presently known range is upper lower Miocene.
Size. Maximum inner diameter 40 to $50 \mu \mathrm{m}$ (holotype $49 \mu \mathrm{m}$ ).

Holotype. USNM 371385 (Plate 5, Fig. 1).

Isotypes. USNM 371386 to 371390 .

Type locality. Equatorial Pacific Ocean, DSDP Sample 575A-8-2, $42-43 \mathrm{~cm}$ (125 m sub-bottom).

\section{Genus NAVICULOPSIS Frenguelli, 1940}

Naviculopsis obtusarca Bukry var. acicula Bukry, n. var. (Plate 6, Figs. 5-9)

Naviculopsis sp. cf. N. obtusarca Bukry, Bukry, 1982a, p. 444, pl. 8, figs. $6,8-10$.

Description. Naviculopsis obtusarca var. acicula has a boat-shaped basal ring with narrow, protruding ends that are rounded. The apical bar is aligned with the minor axis of the ring. The lengths of the solid end-points of the ring are about equal to the maximum width of the ring opening along the minor axis. There are no spines developed, and the end points may have an oblong hyaline area oriented along the major axis.

Remarks. Naviculopsis obtusarca var. acicula is distinguished from $N$. obtusarca by the single, narrow ends of the ring, instead of the blunt or doubly pointed concave ends for $N$. obtusarca. Also, the hyaline area at the end of $N$. obtusarca var. acicula shows elongation along the major axis, not across it. $N$. obtuscarca var. acicula is distinguished from $N$. ponticula by the bowed sides of the basal ring and the protruding, long, narrow ends, and from $N$. navicula by the protruding ends with hyaline areas.

Occurrence. Naviculopsis obtusarca var. acicula occurs in lower Miocene Naviculopsis ponticula Zone Cores 10 and 11 of DSDP Hole 575A and in Core 32 of DSDP Hole 495. Both sources are in the eastern Pacific, on opposite sides of the East Pacific Rise, and probably represent the same or contiguous populations. Populations of $N$. obtusarca from Austria, illustrated by Stradner (1961) and Bachmann (1970), did not reveal specimens of this new variety.

Size. Maximum inner diameter 50 to $60 \mu \mathrm{m}$ (holotype $51 \mu \mathrm{m}$ ).

Holotype. USNM 371391 (Plate 6, Fig. 5).

Isotypes. USNM 371392 to 371395 .

Type locality. Eastern equatorial Pacific, DSDP Sample 575A-10-2, $42-43 \mathrm{~cm}$ (129 m sub-bottom).

\section{SYSTEMATIC PALEONTOLOGY OF NEW COMBINATIONS} Genus DICTYOCHA Ehrenberg, 1837

Dictyocha flexatella (Bukry) Bukry, n. comb.

Dictyocha perlaevis flexatella Bukry, 1979b, p. 984, pl. 3, figs. 1-3.

\section{AUTHORSHIP AND ILLUSTRATION REFERENCES TO PUBLISHED LITERATURE FOR CITED TAXA}

Corbisema triacantha (Ehrenberg) Hanna-Bukry, 1979a Dictyocha aculeata (Lemmermann) Dumitricà-Bukry, 1980b

$D$. angulata Bukry-Bukry, 1982a

D. brevispina ausonia (Deflandre) Bukry-Bukry, 1978a

D. brevispina brevispina (Lemmermann) Bukry-Bukry, 1981a

D. calida calida Poelchau-Poelchau, 1976

D. delicata (Bukry) Bukry-Bukry, 1980b

D. fibula Ehrenberg-Bukry, 1980a

D. longa Bukry-Bukry, 1982a

D. longa var. paxilla Bukry-Bukry, 1982a

D. neonautica Bukry-Bukry, 1981a

D. neonautica var. cocosensis Bukry-Bukry, 1981a

D. orbiculata Ling-Ling, 1977

D. ornata africana Bukry-Bukry, 1982a

D. ornata ornata (Bukry) Bukry-Bukry, 1982a

D. pons Ehrenberg-Bukry, 1980a

D. pulchella Bukry-Bukry, 1980a

D. stapedia stapedia Haeckel-Bukry, 1980b

Distephanus crux crux (Ehrenberg) Haeckel-Ehrenberg, 1854

D. crux parvus (Bachmann) Bukry emend.-Bukry, 1982a

D. crux scutulatus Bukry-Bukry, 1982a

D. hannai (Bukry) Bukry-Bukry, 1975

D. mesophthalmus (Ehrenberg) Haeckel-Bukry, 1982a

D. polyactis (Ehrenberg) Deflandre-Bukry, 1981a 
D. schauinslandii Lemmermann-Lemmermann, 1901

D. speculum haliomma (Ehrenberg) Bukry-Bukry, 1978a

D. speculum hemisphaericus (Ehrenberg) Bukry-Bukry, 1978a

D. speculum patulus Bukry-Bukry, 1982a

D. speculum speculum (Ehrenberg) Haeckel-Bukry, 1980b

D. speculum tenuis Bukry-Bukry, 1982b

D. stauracanthus (Ehrenberg) Haeckel-Dumitricǎ, 1973

D. stradneri (Jerkovíc) Bukry-Stradner, 1961

D. xenus Bukry-Bukry, in press a

Mesocena apiculata apiculata (Schulz) Hanna-Schulz, 1928

M. circulus (Ehrenberg) Ehrenberg-Bukry, 1979b

M. elliptica (Ehrenberg) Ehrenberg-Bukry, 1978b

M. quadrangula Ehrenberg ex Haeckel-Bukry, 1978b

Naviculopsis biapiculata (Lemmermann) Frenguelli-Bukry, 1975

$N$. constricta (Schulz) Bukry emend.-Barron et al., in press

$N$. contraria Bukry-Bukry, 1982a

N. lacrima Bukry-Bukry, 1982a

N. lata (Deflandre) Frenguelli-Bukry, 1978b

N. navicula (Ehrenberg) Deflandre-Bukry, 1982a

N. obtusarca Bukry-Bukry, 1982a

N. ponticula ponticula (Ehrenberg) Bukry-Bukry, 1982a

$N$. ponticula spinosa Bukry-Bukry, 1982a

N. quadrata (Ehrenberg) Ling-Bukry, 1979a

Octactis pulchra Schiller-Bukry, 1980b

\section{CONCLUSIONS}

Silicoflagellates provide a useful relative paleotemperature record that reflects major paleoceanographic events for the lower Miocene to Holocene of Leg 85 sites. For purposes of comparison, the tropical, oceanic setting for the lower Miocene of Hole 575A provides corroboration of major latitudinual trends in silicoflagellate morphology. For example, the virtual absence of fibuloid Dictyoch $a$ at high- and middle-latitude Holes 407, 391A, $370,369 \mathrm{~A}$, and 278 is a cosmopolitan relation because they are, likewise, absent at tropical Hole 575A. Thus, Neogene populations of fibuloid Dictyocha did not become established anywhere until the middle Miocene Corbisema triacantha Zone. This happens to coincide with the time of major transition in silicoflagellate morphologies, which was much more extreme than at the earlier worldwide boundary between Neogene and Paleogene.

The lack of fibuloid Dictyocha in the lower Miocene suggests, further, that no direct lineages exist between the small populations of fibuloid Dictyocha in the Paleogene and those extensive populations of the Neogene, above the lower Miocene.

The early Miocene record of Holes 575A and 495 is distinguished by the absence of the Mesocena apiculata group, which is present at nontropical sites and is most abundant at the coldest site, 278 (Bukry, 1975), south of New Zealand. Because of the absence of Corbisema triacantha in the lower Miocene of Holes 575A and 495, its presence in the lower middle Miocene of Hole 572D, and its lower Miocene occurrences at middle and high latitudes, $C$. triacantha shows a mixed pattern that is less clear than that of Mesocena apiculata.

A pattern of changing paleotemperature values $(T s)$ and species arrays in the Naviculopsis ponticula Zone of Hole $575 \mathrm{~A}$ is practically the same as at Site $\mathbf{4 9 5}$ off Guatemala. Quantitative silicoflagellate data show that tectonic backtracking across the East Pacific Rise should place these two sites in the same vicinity during the period 17 to $19 \mathrm{Ma}$.
High-amplitude fluctuation in silicoflagellate relativepaleotemperature values characterizes the upper Miocene of Hole 572D, which is situated to the east of Hole 575A and at the westernmost position of a modern tongue of cool equatorial waters advected from coastal South America. The substantial populations of cool-water indicator taxon Distephanus speculum speculum suggest the presence of an analogous cool-water tongue as long ago as the late middle Miocene. Following the maximum coolings in the late late Miocene, a general warming trend and reduction in the amplitude of $T s$ fluctuation occurred. The latest major cooling (below $T S=50$ ) occurred in the early Pliocene. Aside from the mid-Quaternary cooling $(T S=71)$ associated with the acme of Mesocena quadrangula, warm Ts values of 80 to 100 are typical for the late Pliocene and Quaternary of Hole 572A.

The low-latitude, open-ocean application of the $T S$ relative-paleotemperature technique appears to be successful for Leg 85, as shown by cool peaks matching deep-sea hiatuses in conjunction with fluctuations of cool and warm currents in the area during the late Cenozoic. Both absolute and relative comparisons of $T s$ values for Leg 85 correlate well within the eastern equatorial Pacific and also reflect global paleoceanographic changes.

\section{ACKNOWLEDGMENTS}

I thank Gerta Keller and Jack G. Baldauf, U.S. Geological Survey, for their helpful reviews of this paper. John A. Barron, U.S. Geological Survey, provided additional samples and excellent background information on diatom correlations for Leg 85, which helped to make a detailed silicoflagellate analysis feasible. I thank Dorothy L. Blackstock, U.S. Geological Survey, for excellent manuscript and figure typing and for proofing the paper.

\section{REFERENCES}

Bachmann, A., 1970. Silicoflagellaten aus dem oberösterreichischen Egerien (Oberoligozän). Österreichische Geol. Bundesanst. Verh., 2:275-305.

Barron, J. A., 1983. Latest Oligocene through early middle Miocene diatom biostratigraphy of the eastern tropical Pacific. Mar. Micropaleontol., 7:487-515.

Barron, J. A., Bukry, D., and Poore, R. Z., in press. Correlation of the middle Eocene Kellog Shale of northern California. Micropaleontology.

Barron, J. A., and Keller, G., 1982. Widespread Miocene deep-sea hiatuses: Coincidence with periods of global cooling. Geology, 10: 577-581.

Bernstein, R. L., and Morris, J. H., 1983. Tropical and mid-latitude North Pacific sea surface temperature variability from the SEASAT SMMR. J. Geophys. Res., 88:1877-1891.

Bukry, D., 1975. Silicoflagellate and coccolith stratigraphy, Deep Sea Drilling Project Leg 29. In Kennett, J. P., Houtz, R. E., et al., Init. Repts. DSDP, 29: Washington (U.S. Govt. Printing Office), 845-872.

1978a. Cenozoic coccolith and silicoflagellate stratigraphy, offshore northwest Africa, Deep Sea Drilling Project Leg 41. In Lancelot, Y., Seibold, E., et al., Init. Repts. DSDP, 41: Washington (U.S. Govt. Printing Office), 689-707.

1978b. Cenozoic coccolith, silicoflagellate, and diatom stratigraphy, Deep Sea Drilling Project Leg 44. In Benson, W: E., Sheridan, R. E., et al., Init. Repts. DSDP, 44: Washington (U.S. Govt. Printing Office), 807-863.

1979a. Coccolith and silicoflagellate stratigraphy, northern Mid-Atlantic Ridge and Reykjanes Ridge, Deep Sea Drilling Project Leg 49. In Luyendyk, B. P., Cann, J. P., et al., Init. Repts. DSDP, 49: Washington (U.S. Govt. Printing Office), 551-581. 
1979b. Comments on opal phytoliths and stratigraphy of Neogene silicoflagellates and coccoliths at Deep Sea Drilling Project Site 397 off northwest Africa. In Luyendyk, B. P., Cann, J. R., et al., Init. Repts. DSDP, 49: Washington (U.S. Govt. Printing Office), 977-1009.

1980a. Miocene Corbisema triacantha Zone phytoplankton from Deep Sea Drilling Project Sites 415 and 416, off northwest Africa. In Lancelot, Y., Winterer, E. L., et al., Init. Repts. DSDP, 50: Washington (U.S. Govt. Printing Office), 507-523.

, 1980b. Silicoflagellate biostratigraphy and paleoecology in the eastern equatorial Pacific, Deep Sea Drilling Project Leg 54. In Rosendahl, B. R., Hekinian, R., et al., Init. Repts. DSDP, 54: Washington (U.S. Govt. Printing Office), 545-573.

1981a. Silicoflagellate stratigraphy of offshore California and Baja California, Deep Sea Drilling Project Leg 63. In Yeats, R. S., Haq, B. U., et al., Init. Repts. DSDP, 63: Washington (U.S. Govt. Printing Office), 539-557.

$1981 \mathrm{~b}$. Synthesis of silicoflagellate stratigraphy for Maestrichtian to Quaternary marine sediment. Soc. Econ. Paleontol. Mineral. Spec. Publ., 32:433-444.

, 1982a. Cenozoic silicoflagellates from offshore Guatemala, Deep Sea Drilling Project Site 495. In Aubouin, J., von Huene, R., et al., Init. Repts. DSDP, 67: Washington (U.S. Govt. Printing Office), 425-445.

1982b. Neogene silicoflagellates of the eastern equatorial Pacific, Deep Sea Drilling Project Hole 503A. In Prell, W. L., Gardner, J. V., et al., Init. Repts. DSDP, 68: Washington (U.S. Govt. Printing Office), 311-323.

1983. Upper Cenozoic silicoflagellates from offshore Ecuador, Deep Sea Drilling Project Site 504. In Cann, J. R., Langseth, M. G., Honnorez, J., Von Herzen, R. P., White, S. M., et al., Init. Repts. DSDP, 69: Washington (U.S. Govt. Printing Office), 321-342.

, in press a. Cenozoic silicoflagellates from Rockall Plateau, Deep Sea Drilling Project Leg 81. In Roberts, D. G., Schnitker, D., et al., Init. Repts. DSDP, 81: Washington (U.S. Govt. Printing Office).

, in press b. Neogene silicoflagellates from DSDP Site 543 , western tropical Atlantic Ocean. In Hyndman, R. D., Salisbury, M. H., et al., Init. Repts. DSDP, 78B: Washington (U.S. Govt. Printing Office).

Bukry, D., and Foster, J. H., 1974. Silicoflagellate zonation of Upper Cretaceous to lower Miocene deep-sea sediment. U.S. Geol. Surv. J. Res., 2:303-310.
Dumitricǎ, P., 1973. Paleocene, late Oligocene and post-Oligocene silicoflagellates in southwestern Pacific sediments cored on DSDP Leg 21. In Burns, R. E., Andrews, J. E., et al., Init. Repts. DSDP, 21: Washington (U.S. Govt. Printing Office), 837-883.

Ehrenberg, C. G., 1840. 274 Blätter von ihm selbst ausgeführter Zeichnungen von ebenso vielen Arten. $K$. Preuss. Akad. Wiss. Berlin Ber. Jahrg., 1840(Nov.):197-219.

1854. Mikrogeologie: Leipzig (Leopold Voss), pp. 1-374.

Hays, J. D., et al., 1972. Init. Repts. DSDP, 9: Washington (U.S. Govt. Printing Office).

Keller, G., and Barron, J. A., 1983. Paleoceanographic implications of Miocene deep-sea hiatuses. Geol. Soc. Am. Bull., 94:590-613.

Lemmermann, E., 1901. Silicoflagellatae. Deutsche. Bot. Gesell. Ber., 19:247-271.

Ling, H. Y., 1977. Late Cenozoic silicoflagellates and ebridians from the eastern North Pacific region. First Internat. Congr. Pacific Neogene Stratigraphy Proc. (Tokyo), pp. 205-233.

Locker, S., 1974. Revision der Silicoflagellaten aus der Mikrogeologischen Sammlung von C. G. Ehrenberg. Eclogae Geol. Helvetiae, 67:631-646.

Major, R. P., and Matthews, R. K., 1983. Isotopic composition of bank margin carbonates on Midway Atoll: Amplitude constraint on post-early Miocene eustasy. Geology, 11:335-338.

Martini, E., 1971. Neogene silicoflagellates from the equatorial Pacific. In Winterer, E. L., Riedel, W. R., et al., Init. Repts. DSDP, 7, Pt. 2: Washington (U.S. Govt. Printing Office), 1695-1708.

Poelchau, H. S., 1976. Distribution of Holocene silicoflagellates in North Pacific sediments. Micropaleontology, 22:164-193.

Schulz, P., 1928. Beiträge zur Kenntnis fossiler und rezenter Silicoflagellaten. Bot. Archiv, 21:225-292.

Shackleton, N. J., 1982. The deep-sea sediment record of climate variability. Prog. Oceanogr., 11:199-218.

Stradner, H., 1961. Über fossile Silicoflagelliden und die Möglichkeit ihrer Verwendung in der Erdölstratigraphie. Erdol Kohle, 14:87-92.

Vail, P. R., Mitchum, R. M., Jr., and Thompson, S., 1977. Global cycles of relative changes of sea level. In Payton, C. E. (Ed.), Seismic stratigraphy-applications to hydrocarbon exploration: Tulsa (Am. Assoc. Pet. Geol.), pp. 83-98.

van Andel, T. H., and Bukry, D., 1973. Basement ages and basement depths in the eastern equatorial Pacific from Deep Sea Drilling Project Legs 5, 8, 9, and 16. Geol. Soc. Am. Bull., 84:2361-2370.

Date of Initial Receipt: 28 October 1983

Date of Acceptance: 6 March 1984 


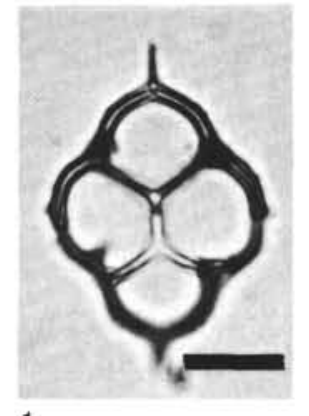

1

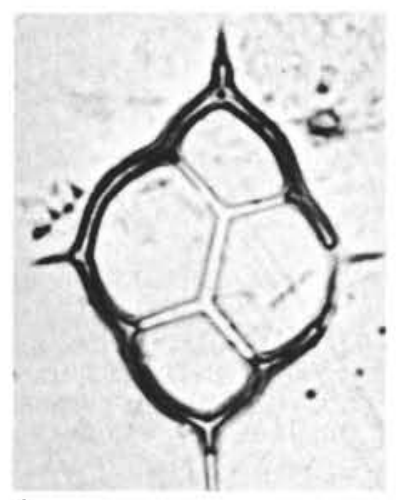

4

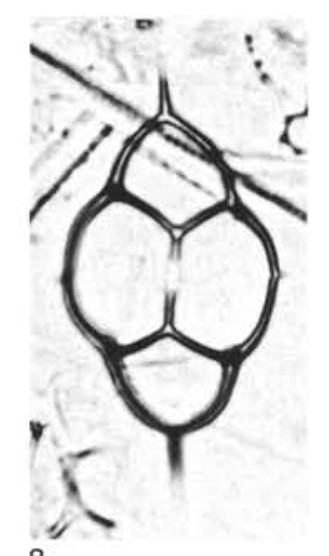

8

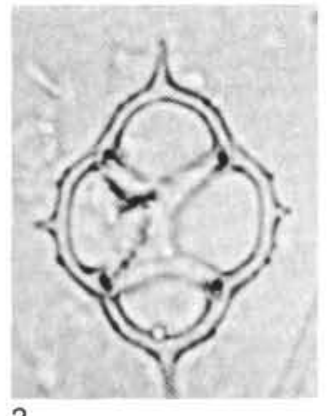

2

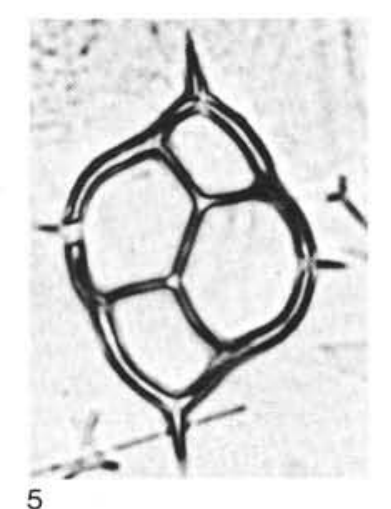

5

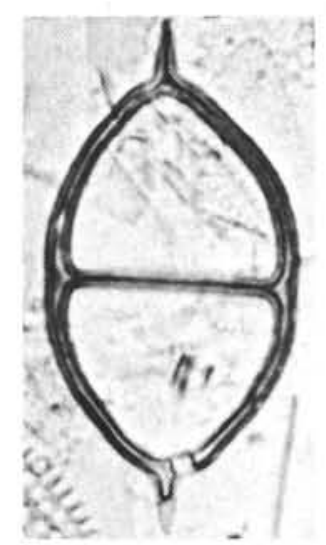

9

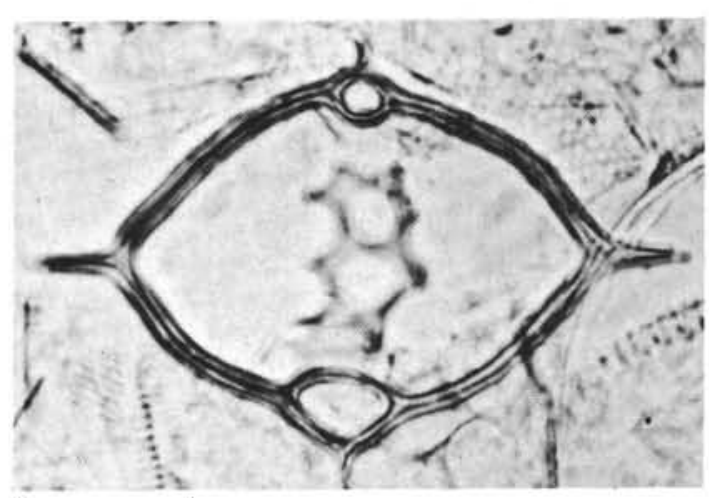

3

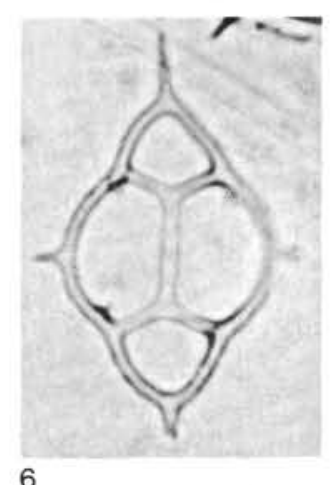

6
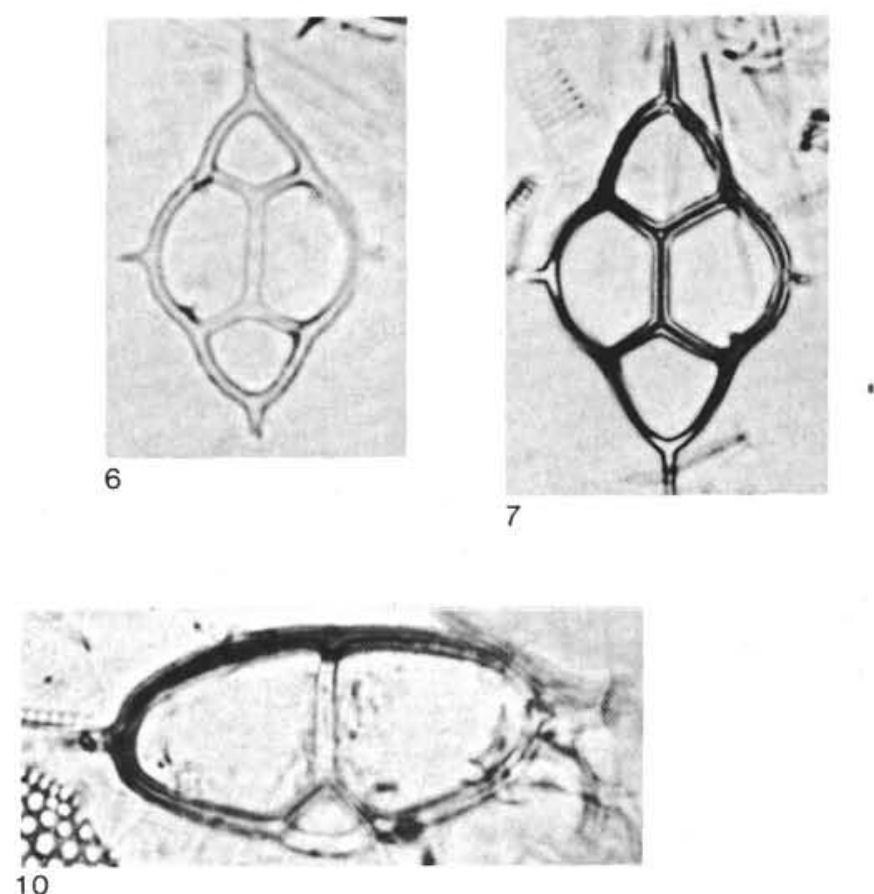

10

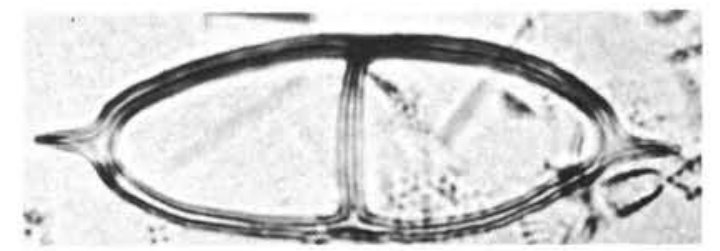

11

Plate 1. Silicoflagellates from DSDP Leg 85. (Scale bar $=10 \mu \mathrm{m}$.) 1-2. Dictyocha angulata Bukry, Sample 572A-7-4, 66-67 cm. 3. Dictyocha brevispina (Lemmermann) (no bar), Sample 572A-10,CC. A form identical to the coeval (approx. 4.5 Ma) population in Section 504-45-1 (Bukry, 1983), which also lacks barred asperoid specimens. 4-5. Dictyocha flexatella (Bukry), Sample 572A-5-3, 16-17 cm. 6-8. Dictyocha longa Bukry, (6) Sample 572A-8-3, 66-67 cm, (7) Sample 572A-8-3, 16-17 cm, (8) rounded ends, Sample 572A-8-3, 16-17 cm. 9. Dictyocha neonautica var. cocosensis Bukry, Sample 572A-14,CC. 10-11. Dictyocha neonautica Bukry, Sample 572A-15-1, 68-69 cm, (10) transitional specimen, (11) normal specimen. 

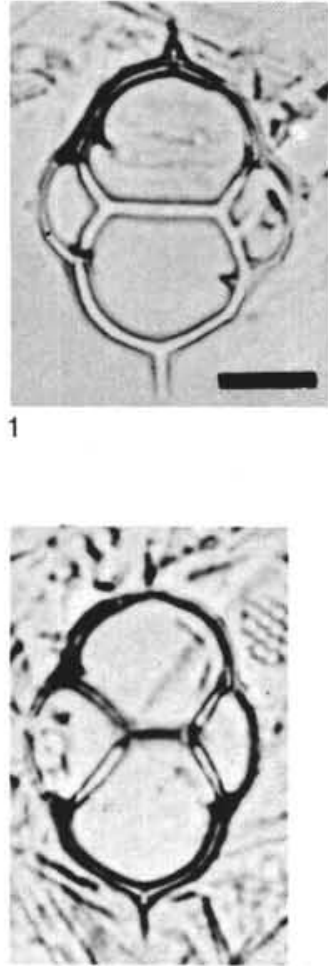

5

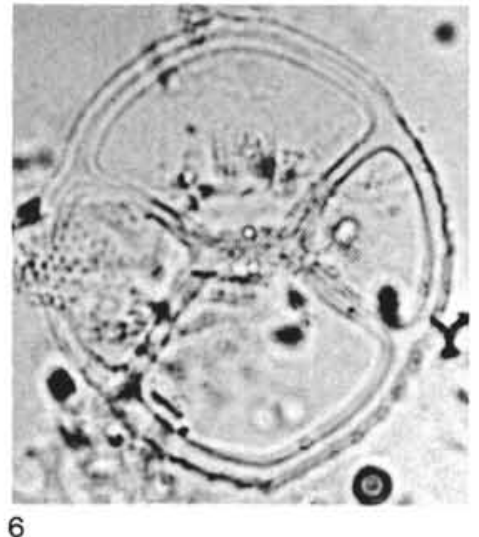

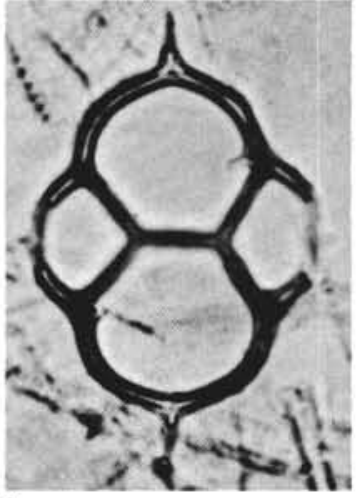

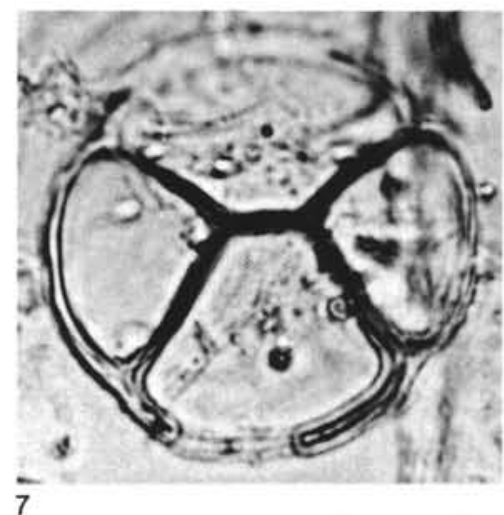

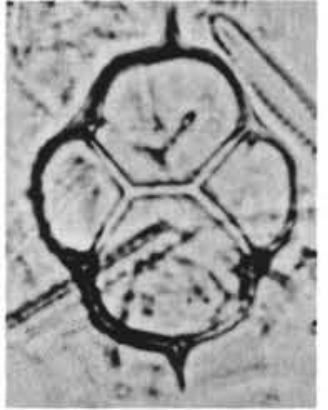

4

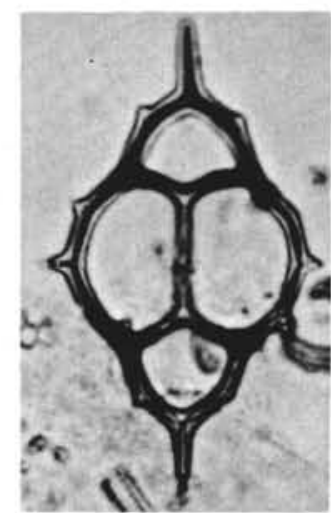

8

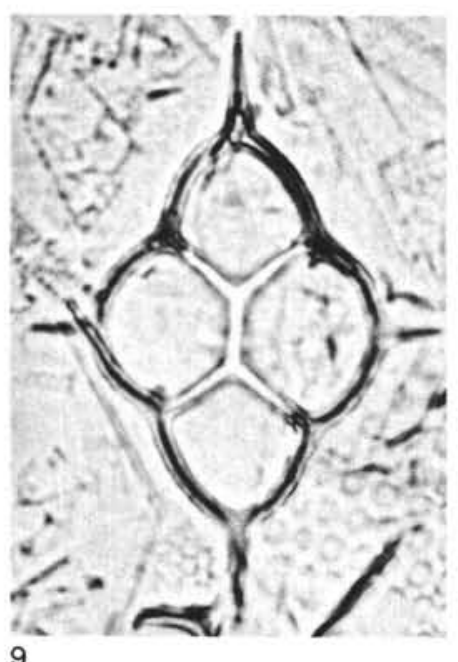

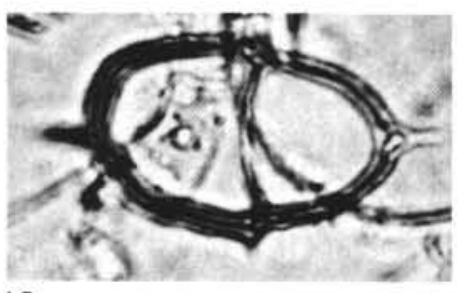

10

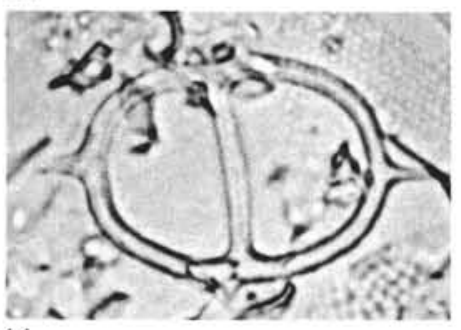

11

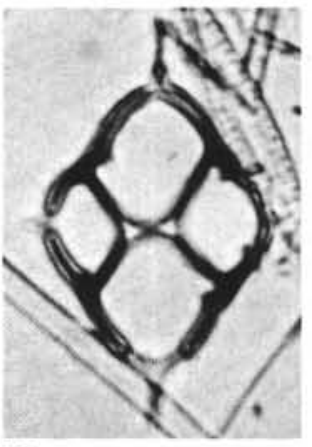

12

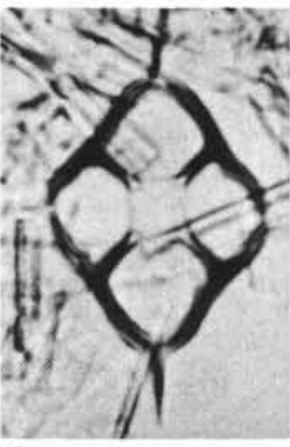

13

Plate 2. Silicoflagellates from DSDP Leg 85. (Scale bar $=10 \mu \mathrm{m}$.) 1-5. Dictyocha nola Bukry, n. sp., Sample 572A-11-3, 67-68 cm, (1) USNM 371374, (2) USNM 371375, (3) holotype, USNM 371373, (4) USNM 371376, (5) USNM 371377. 6-7. Dictyocha orbiculata Ling, Sample 572A-7,CC. 8. Dictyocha ornata africana (Bukry), Sample 572A-5,CC. 9. Dictyocha perfecta Bukry, Sample 572A-8-3, 66-67 cm. 10-11. Dictyocha pons Ehrenberg, Sample 575A-1,CC. 12-13. Dictyocha pulchella Bukry, Sample 572D-18,CC, (12) normal specimen, (13) deflandroid specimen. 

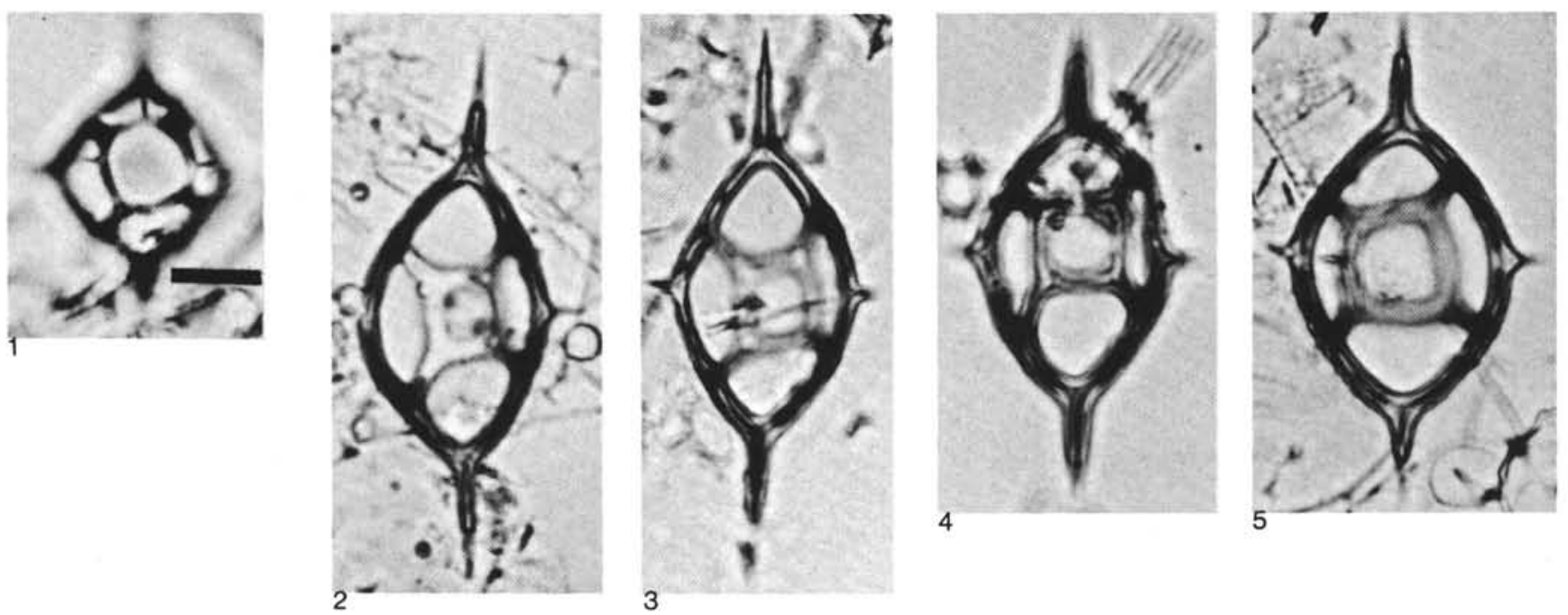

3
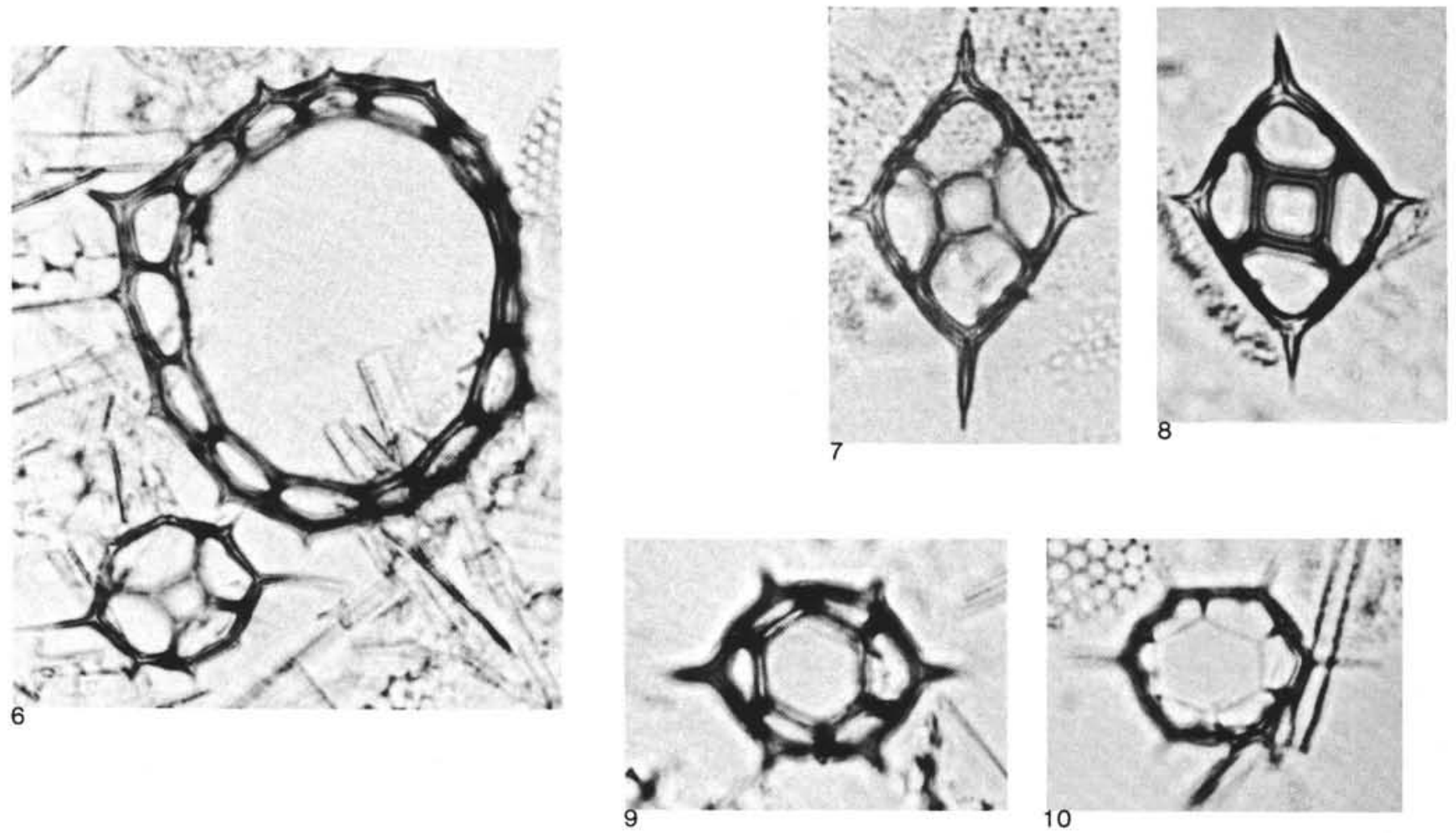

Plate 3. Silicoflagellates from DSDP Leg 85. (Scale bar $=10 \mu \mathrm{m}$.) 1. Distephanus mesophthalmus (Ehrenberg), Sample 572A-15-3, 19-20 cm. 2-5. Distephanus schauinslandii Lemmermann, (2) Sample 575A-18,CC, (3) Sample 575A-11-3, 24-25 cm, (4) Sample 575A-18,CC, (5) Sample 575A-17,CC. 6. Distephanus polyactis (Ehrenberg) above Distephanus stauracanthus (Ehrenberg), Sample 572D-22,CC. 7-8. Distephanus crux scutulatus Bukry, (7) Sample 575A-12,CC, (8) Sample 575A-7-2, 42-43 cm. 9. Distephanus speculum patulus Bukry, Sample 575A19 ,CC. 10. Distephanus speculum tenuis Bukry, Sample 572A-16-3, 19-20 cm. 


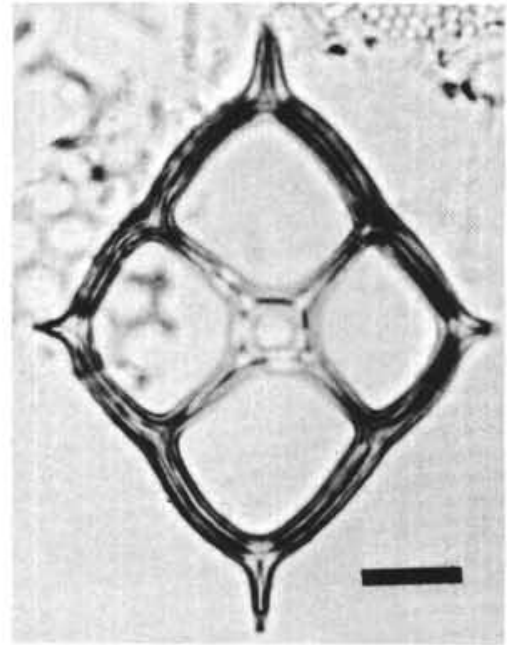

1

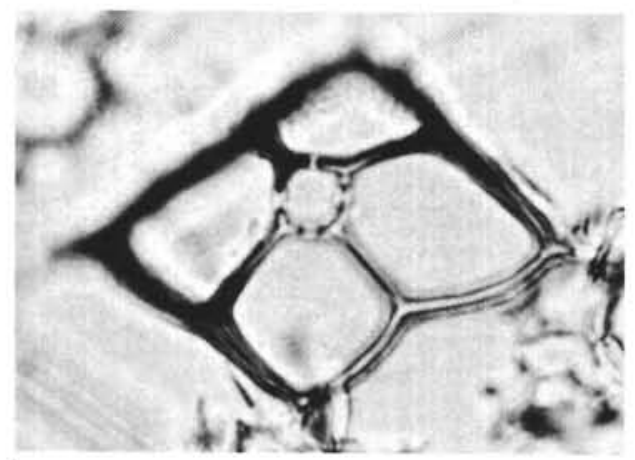

4

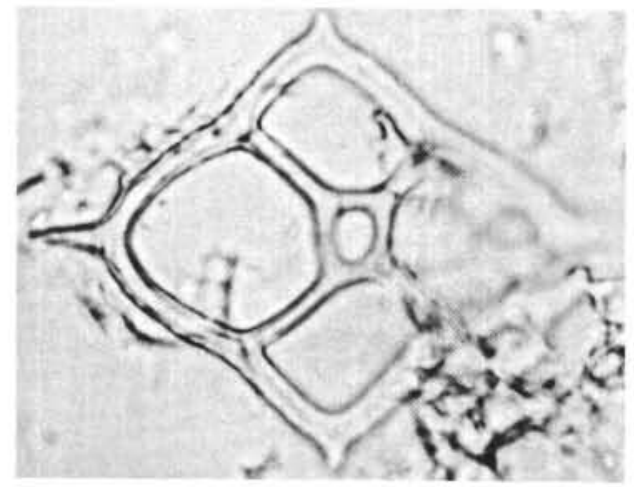

7

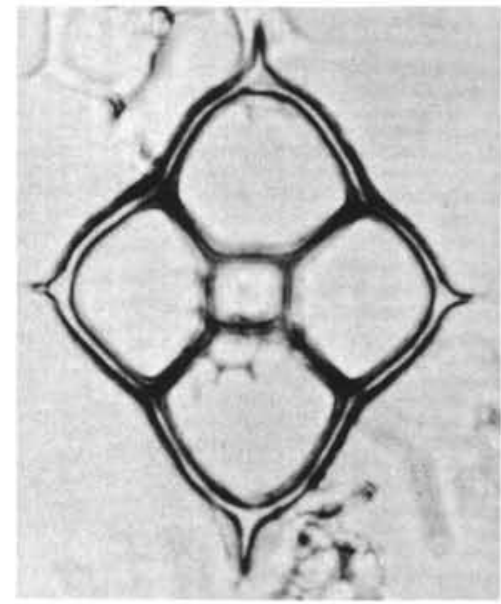

2

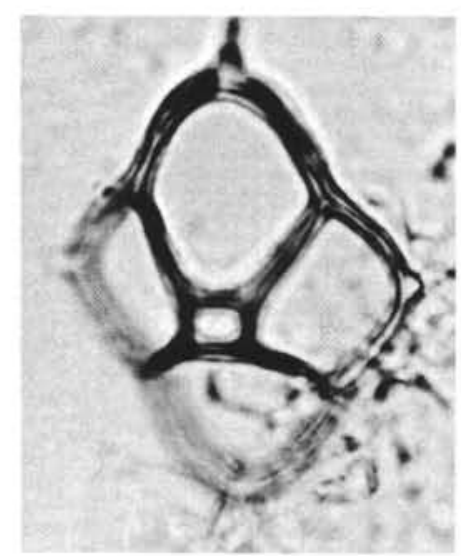

5

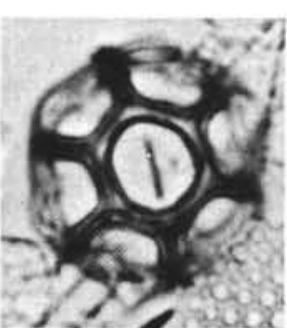

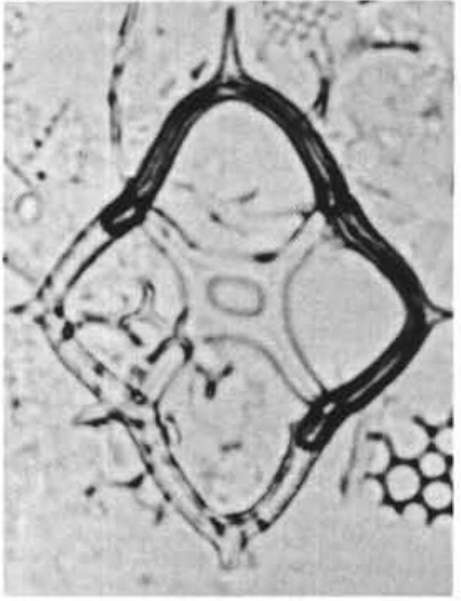

3

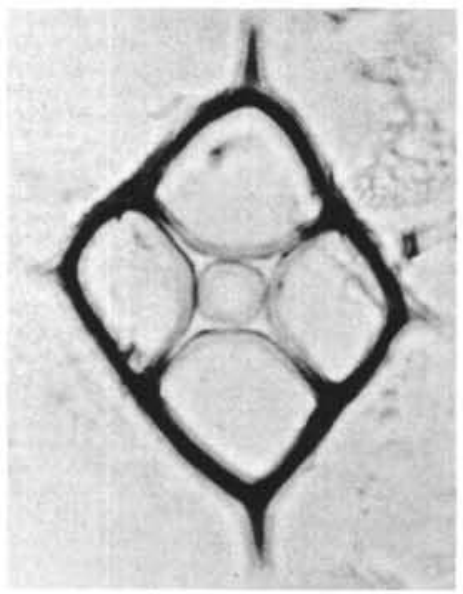

6

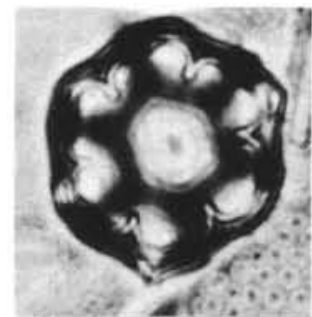

Plate 4. Silicoflagellates from DSDP Leg 85 . (Scale bar $=10 \mu \mathrm{m}$.) 1-7. Distephanus stradneri var. grandis Bukry, n. var., Sample 575A-33,CC, (1) USNM 371379, (2) holotype, USNM 371378, (3) USNM 371380, (4) USNM 371381, (5) USNM 371382, (6) USNM 371383, (7) USNM 371384. 8-9. Distephanus xenus Bukry, Sample 572A-14-3, 18-19 cm, (8) apical focus, (9) basal focus. 


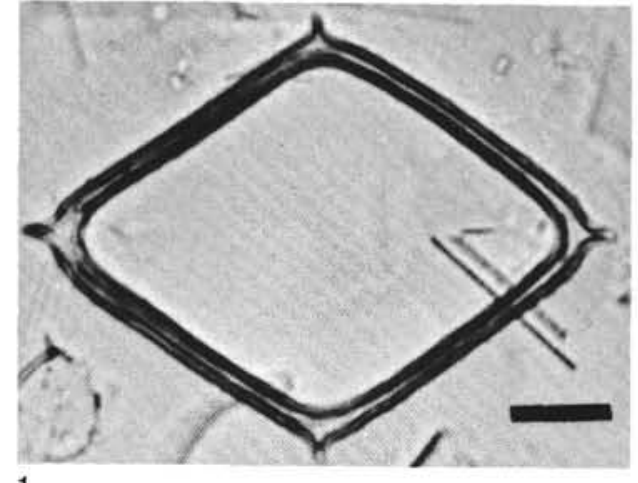

1

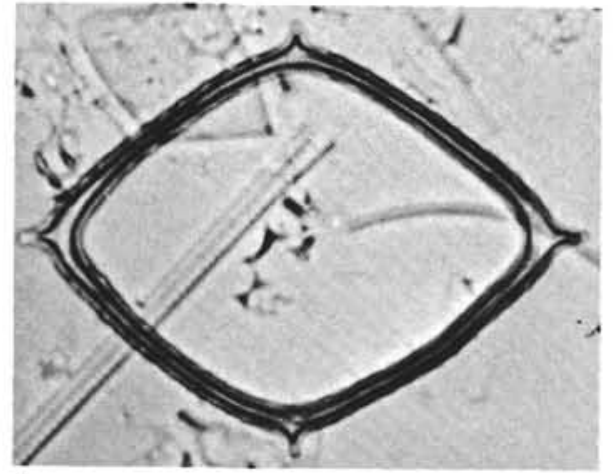

4

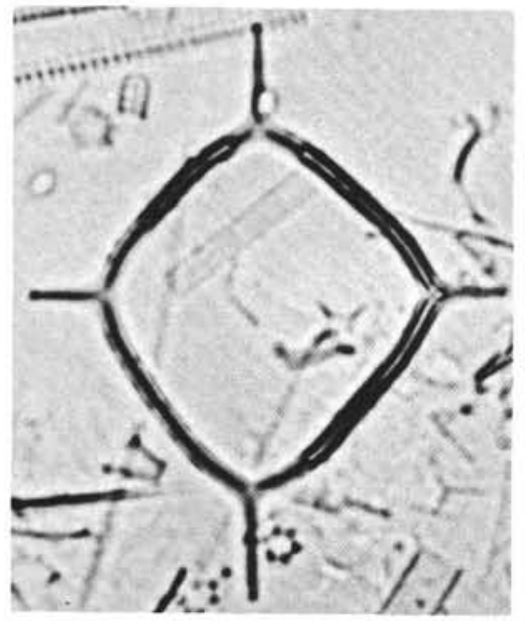

7

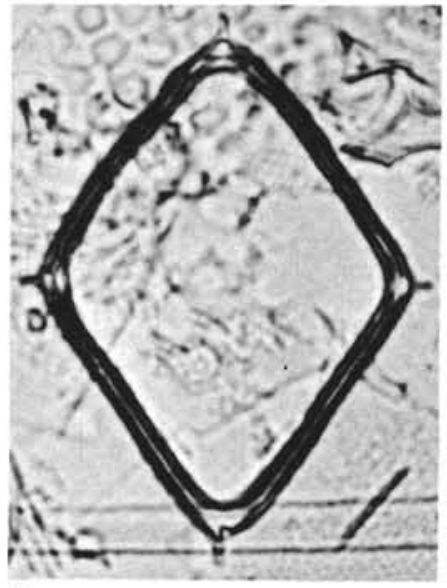

2

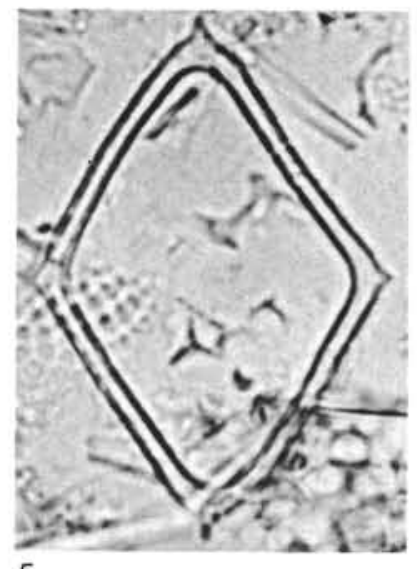

5

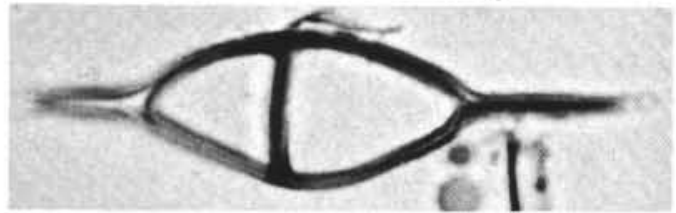

8

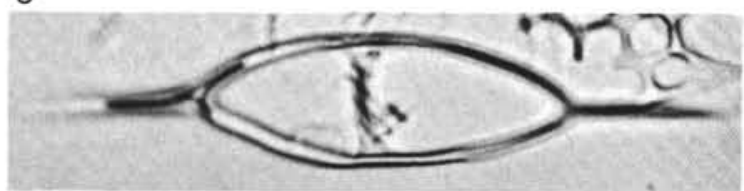

9
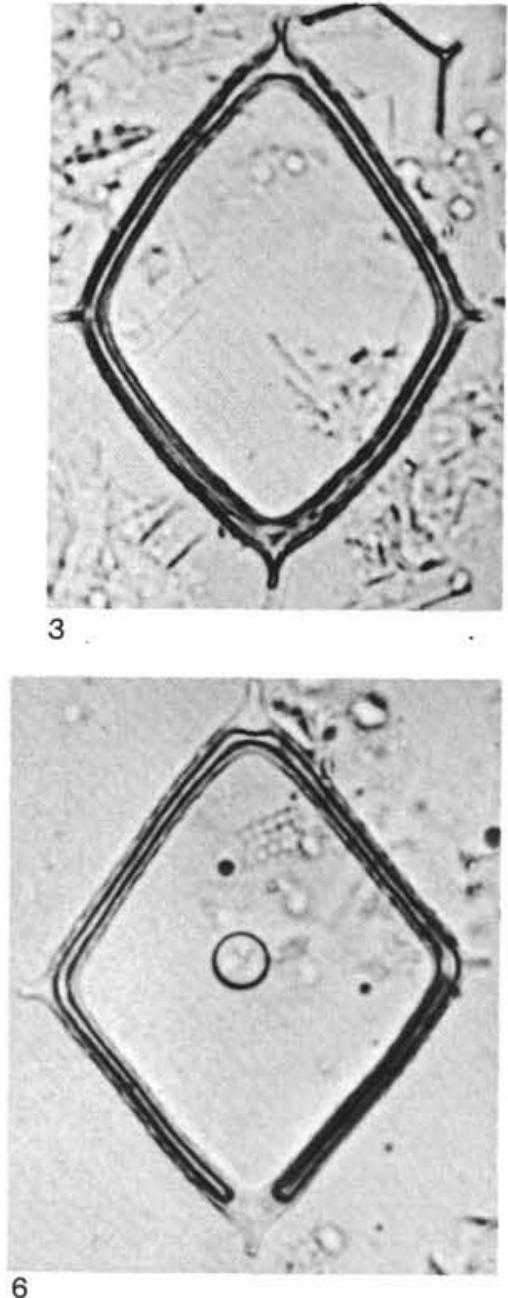

Plate 5. Silicoflagellates from DSDP Leg 85. (Scale bar $=10 \mu \mathrm{m}$.) 1-6. Mesocena elliptica var. rhomboidea Bukry, $\mathrm{n}$. var., (1) holotype, USNM 371385, Sample 575A-8-2, 42-43 cm, (2) USNM 371386, Sample 575A-9, CC, (3) USNM 371387, Sample 575A-7-3, 24-25 cm, (4) USNM 371388, Sample 575A-8-2, 42-43 cm, (5) USNM 371389, Sample 575A-7,CC, (6) USNM 371390, Sample 575A-10,CC. 7. Mesocena quadrangula Ehrenberg ex Haeckel, Sample 572A-3-1, 68-69 cm. 8-9. Naviculopsis biapiculata (Lemmermann) s. ampl., (8) Sample 575A-19,CC, (9) Sample 575A-17,CC. 


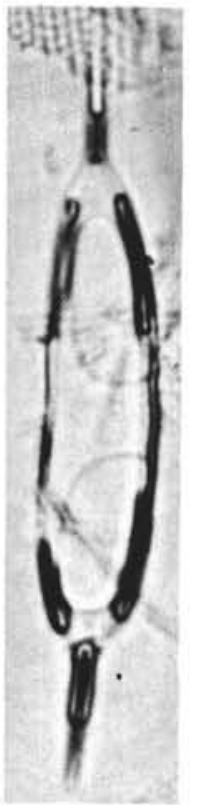

1

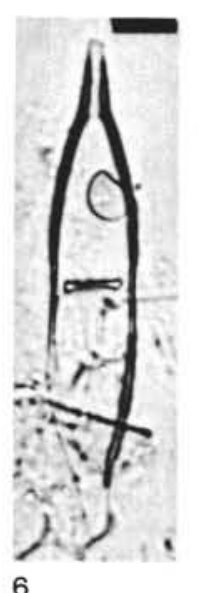

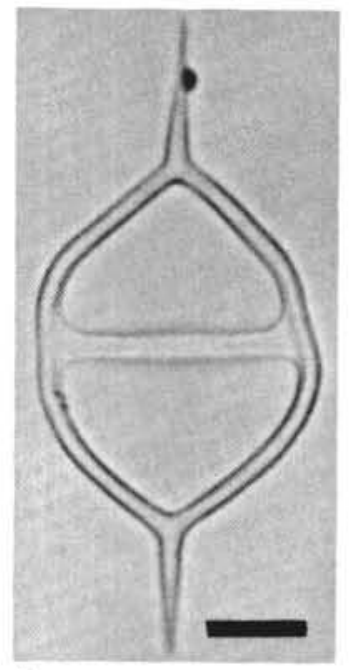

2

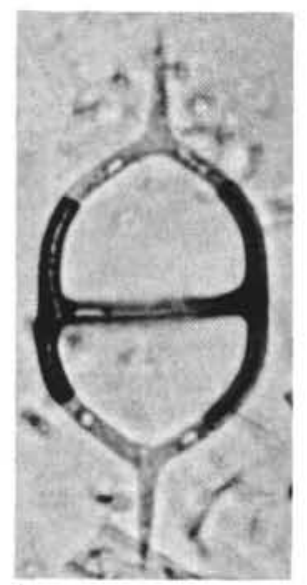

3

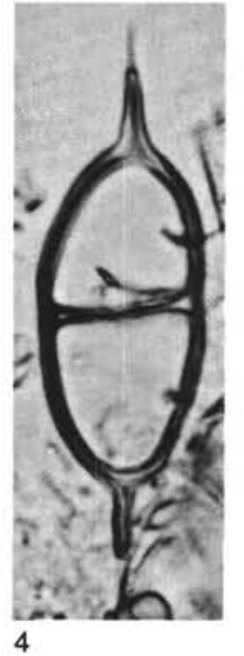

4

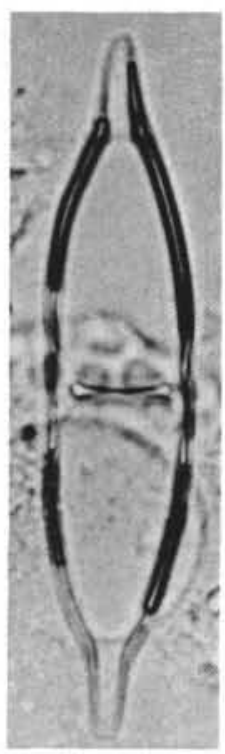

5

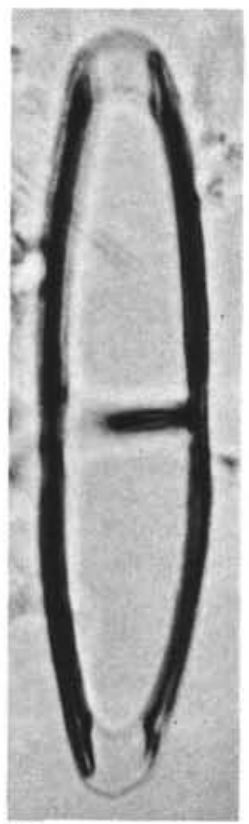

11

Plate 6. Silicoflagellates from DSDP Leg 85. (Scale bar for Figs. 1-5 and 7-11 =10 $\mu \mathrm{m}$. Scale bar for Fig. $6=20 \mu \mathrm{m}$.) 1. Naviculopsis contraria Bukry, Sample 575A-9,CC. 2-4. Naviculopsis lata (Deflandre), (2) hexagonal, Sample 575A-20,CC, (3) normal, Sample 575A-19,CC, (4) narrow, Sample 575A-19,CC. 5-9. Naviculopsis obtusarca var. acicula Bukry, n. var., (5) holotype, USNM 371391, Sample 575A-10-2, 42-43 cm, (6) USNM 371392, Sample 575A-10-2, 42-43 cm, (7) USNM 371393, Sample 575A-10-2, 42-43 cm, (8) USNM 371394, Sample 575A-10-3, 42-43 cm, (9) USNM 371395, Sample 575A-10-3, 42-43 cm. 10-11. Naviculopsis ponticula (Ehrenberg), (10) vestigial spine, Sample 575A-7-2, 42-43 cm, (11) smooth end, Sample 575A-7-3, 24-25 cm. 